\title{
UNDERSTANDING AFRICAN AMERICAN COMMUNITY COLLEGE TRANSFER STUDENTS' EXPERIENCES: A QUALITATIVE CASE STUDY

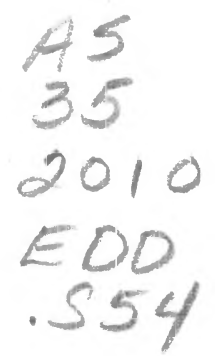

A dissertation submitted to the faculty of

San Francisco State University

In partial fulfillment of

The Requirements for

The Degree

Doctorate of Education

In

Educational Leadership

By

Stacey Koren Shears

San Francisco, California

August 2010 
Copyright by

\section{Stacey Koren Shears}

2010 


\section{CERTIFICATION OF APPROVAL}

I certify that I have read Understanding African American Community College Transfer Students' Experiences: A Qualitative Case Study by Stacey Koren Shears, and that in my opinion this work meets the criteria for approving a dissertation submitted in partial fulfillment of the requirements for the degree: Doctorate of Education in Educational Leadership at San Francisco State University.

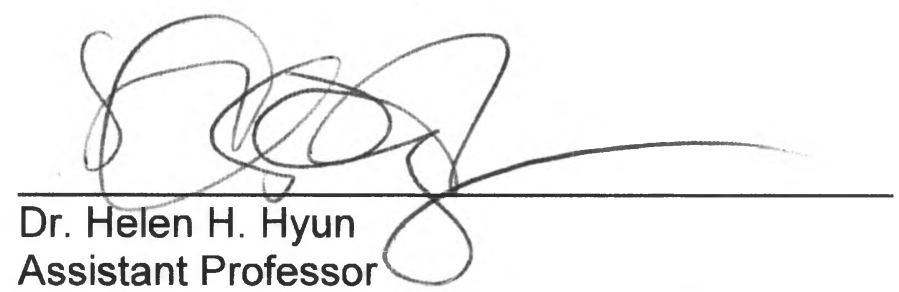

Department of Administration and Interdisciplinary Studies

San Francisco State University

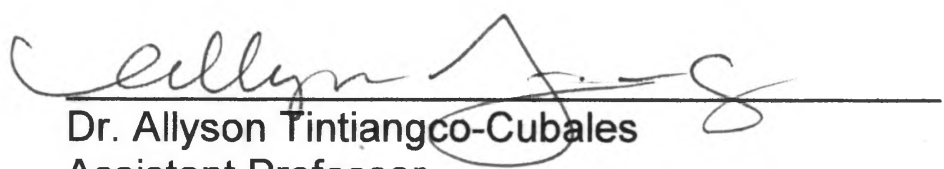
Assistant Professor Asian American Studies San Francisco State University

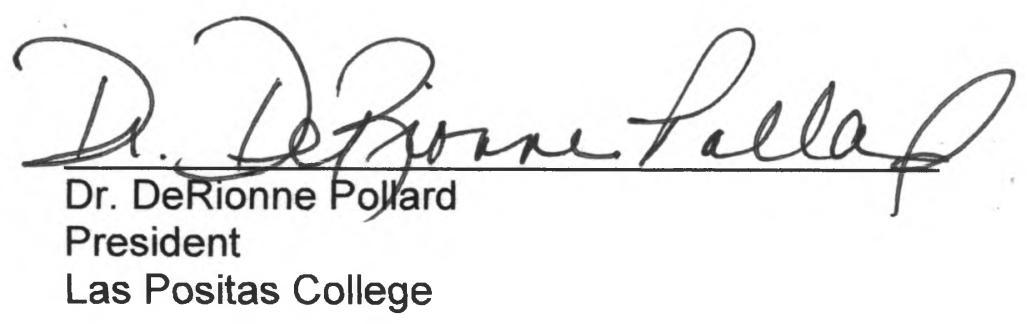




\title{
UNDERSTANDING AFRICAN AMERICAN COMMUNITY COLLEGE
} TRANSFER STUDENTS' EXPERIENCES: A QUALITATIVE STUDY

\author{
Stacey Koren Shears \\ San Francisco, California \\ 2010
}

This dissertation explores the facilitators and barriers for African American students who transferred from a Northern California community college district to a four-year institution. The study examines the particular importance of counseling and interpersonal relationships in the successful transfer of African American students. The study's qualitative methodology and Critical Race Theory framework emphasize student voice through indepth interviewing and counter-storytelling. Study findings suggest that Othermothering, a type of authentic care unique to the African American experience, and transformational resistance serve to ameliorate the persistent racialized experiences of African American community college students that often derail their transfer aspirations.

I certify that the Abstract is a correct representation of the content of this dissertation.

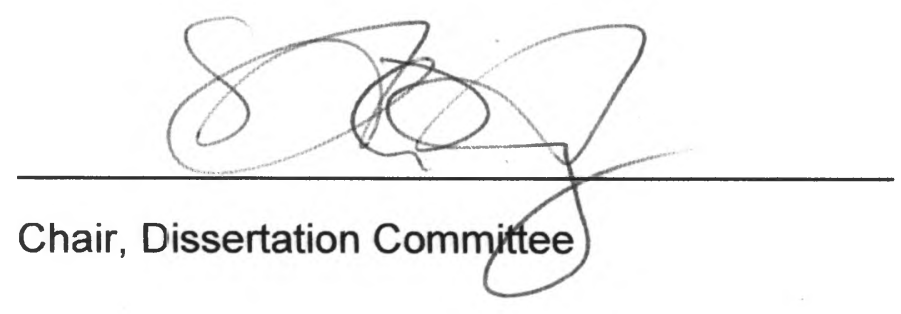

$$
5-21-10
$$

Date 


\section{ACKNOWLEDGMENTS}

Alafia to all the ancestors upon whose shoulders I stand, Olódùmarè and all the Orisa. Modupe for your blessings!

To my mother Dione, and my late father Richard, thank you for teaching me to cherish life, love people, and value education. To my sister Shawnn and niece Pascale, thank you for believing in me. To my friends, thank you for believing in me. Celeste, you cheered me on every step of the way, thank you for your support.

To Dr. Helen H. Hyun, my advisor and chairperson, thank you so much for expanding my thinking and for your expertise, patience, sincerity, and unwavering support. I am honored to work with you and look forward to collaborating in the future. Your unique teaching style, blend of challenge, support, and realism has grounded me throughout this intense experience. To Dr. Allyson Tintiangco-Cubales, your gift of time and authentic feedback has assisted the study and hopefully African American transfer students in the East Bay. To Dr. DeRionne Pollard, your insight, friendship, and support have been invaluable to me. Thank you for your heartfelt encouragement throughout this process.

To the students who participated in this study, thank you for sharing your experiences and frustrations, and providing me with honest feedback.

I also want to thank the SFSU EDDL Cohort 1 students and staff members. I am honored to be associated with all of you. We made it! 


\section{TABLE OF CONTENTS}

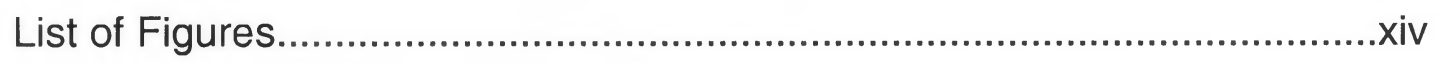

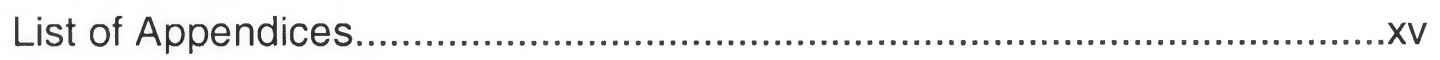

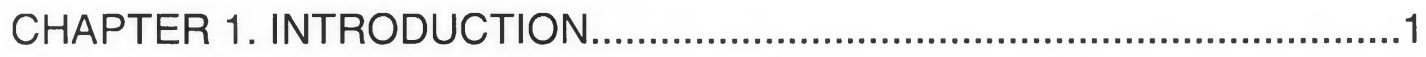

Introduction and Problem Statement..............................................

Research Questions and Proposition............................................

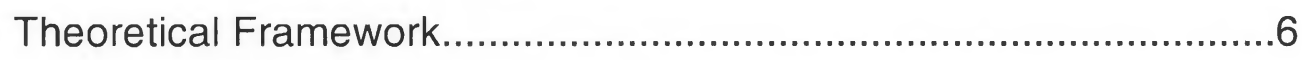

Positioning the Researcher........................................................... 10

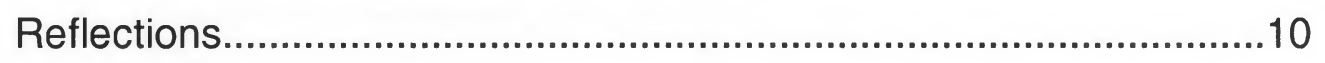

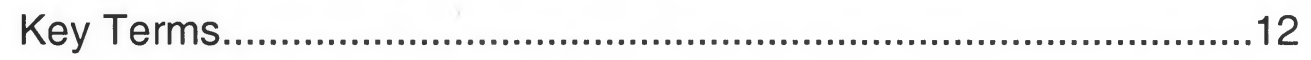

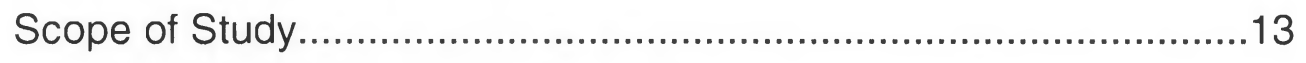

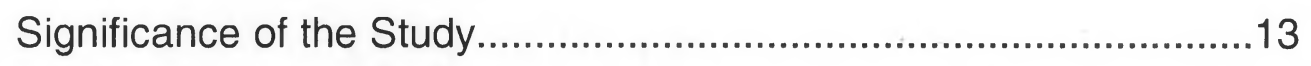

Organization of Chapters.................................................................15 
Community College Student Challenges...........................................18

California Community College Student Demographics.....................18

African American College Students..................................................20

Facilitators for Community College Transfer...................................22

African American Community College Transfer Students..................24

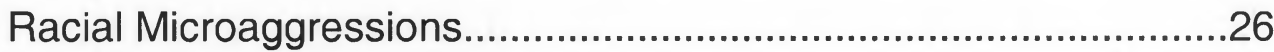

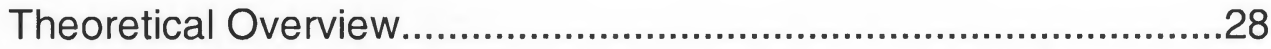

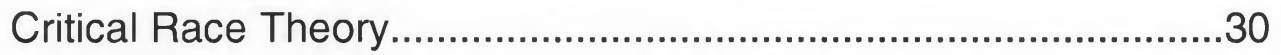

Transformational and Resilient Resistance.......................................35

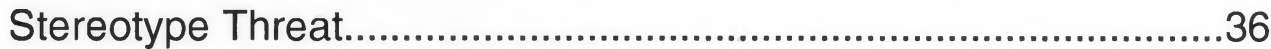

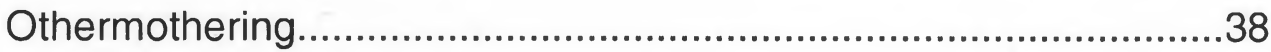

Intersection of CRT and Othermothering........................................41 
Overview. 44

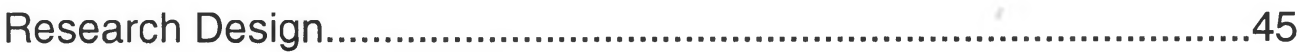

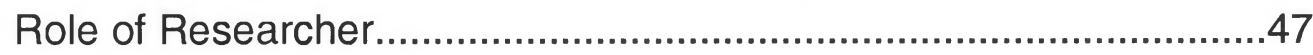

Proposition and Research Questions............................................49

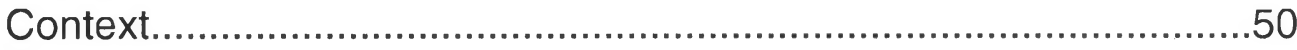

Participant Selection.......................................................................52

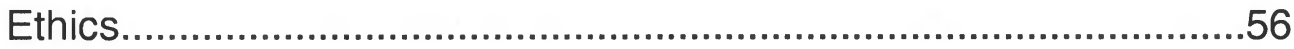

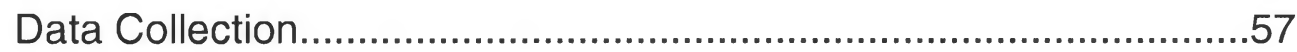

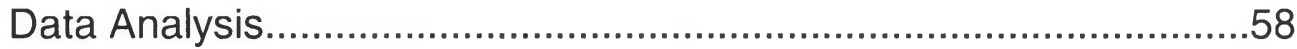

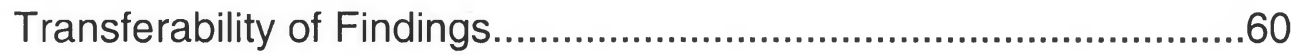

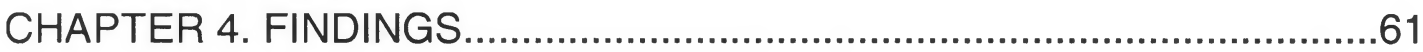

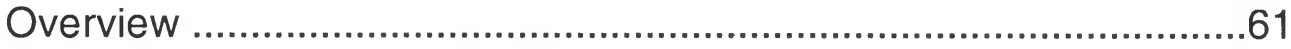




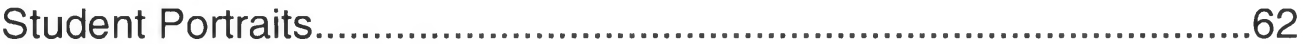

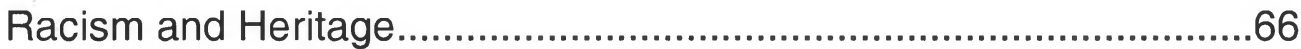

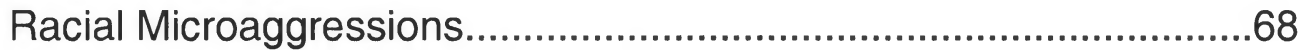

African American Heritage...............................................................

Othermothering Support...................................................................

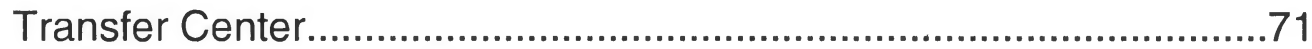

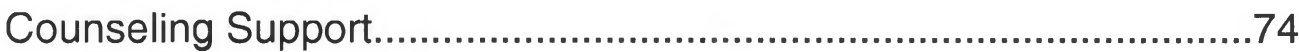

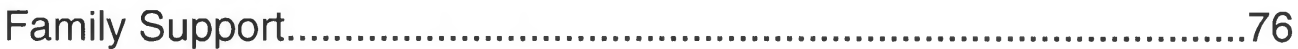

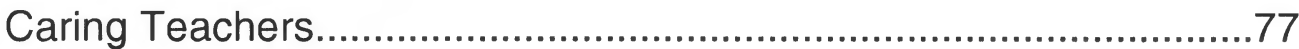

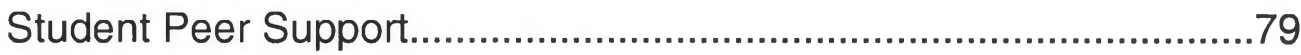

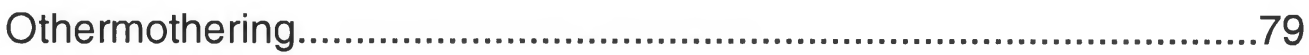

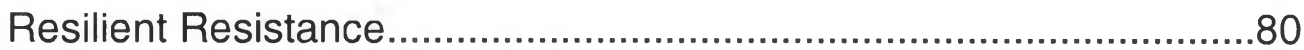

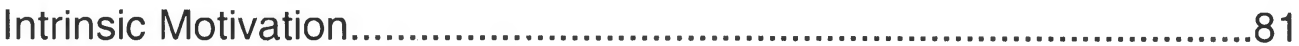




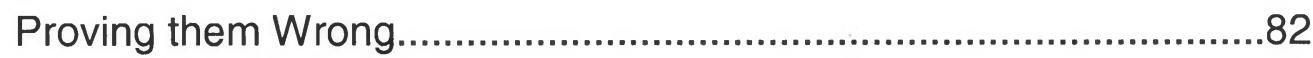

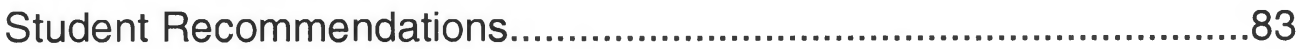

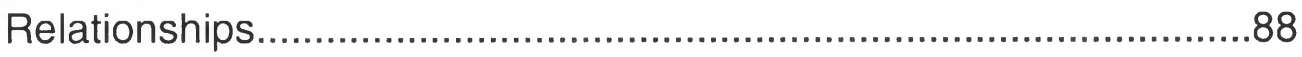

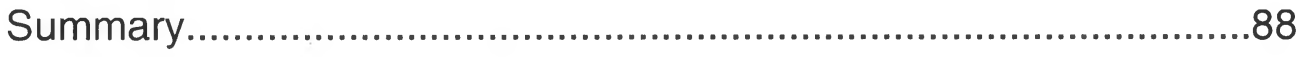

CHAPTER 5. CONCLUSIONS AND RECOMMENDATIONS.......................89

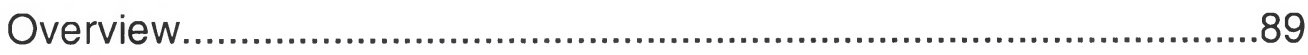

Racial Microaggression................................................................92

The Role of Othermothering............................................................94

Transformational Resistance........................................................96

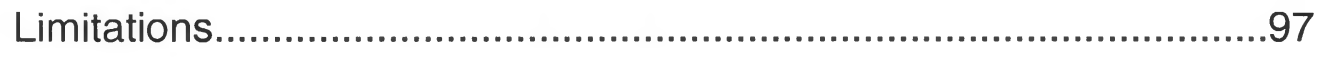

Implications for Improving Practice.................................................97

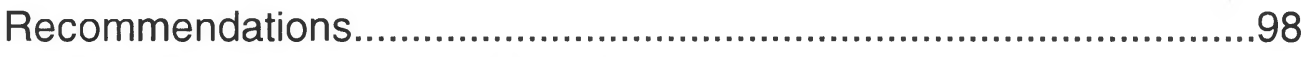

Implications for Future Research..................................................102 


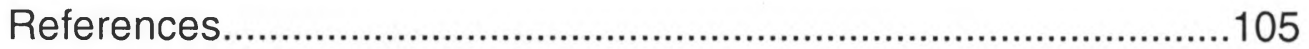

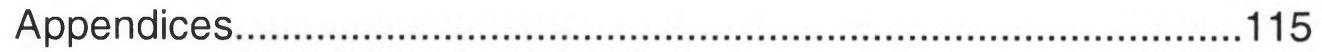




\section{LIST OF FIGURES}

Figure

Page

Figure 1. Theory Interaction ....................................................... 7

Figure 2. Convergence of Othermothering and Critical Race Theory .......... 41

Figure 3. Participant Community College Attendance ............................... 54

Figure 4. Participants' Majors........................................................... 55

Figure 5. Participants' Generation Attending College ............................. 56 


\section{LIST OF APPENDICES}

Appendix

Page

A Research Findings Pertaining to Barriers and Facilitators for African

Americans in Community Colleges and Higher Education Overall ....112

B Research Questions........................................................ 113

C Demographic Information of the Colleges of Participants in the 2007

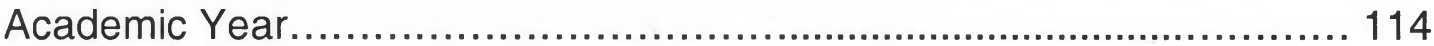

D Pre-Interview Activity .................................................... 115

E Interview Questions................................................116 


\section{CHAPTER 1. INTRODUCTION}

\section{Introduction and Problem Statement}

The history of American education is full of structural inequity. The outcomes of public education in the United States have been differentiated by race and class (Carnoy \& Levin, 1985). Even though school systems have been funded by local property taxes, poor areas have had poorly resourced schools and students attending those schools have fared poorly with few prospects for employment (Petrovich \& Wells, 2005). As Ravitch (1983) noted, public schools for Black students did not lead to jobs. This is problematic since education and specifically higher education is a vehicle for disenfranchised Black students to obtain better paying jobs.

These inequities begin in grades $\mathrm{P}-12$ and continue through higher education. Unfortunately, there is an achievement gap and Black students are less likely than White students to finish high school. And even when they earn high school diplomas, they are less likely than White students to complete a community college credential and to transfer to a four-year university. The end result is that in the year 2000, 6-year-old White children in the first grade were twice as likely as Black children to complete a college degree (Johnson \& Viadero, 2000). Therefore, Black students have fewer 
opportunities than White students for an enhanced standard of living afforded by higher education.

Higher education can provide a vehicle for disenfranchised Black students to achieve a greater standard and quality of life. Bensimon, Hao, and Bustillos (2003) suggested that educational outcomes for African Americans have worsened over time in California. Between 1980 and 2000, the gap between White and Black bachelor-degree attainment increased from $14.7 \%$ to $22.6 \%$. The authors' California Academic Equity Scorecard calculated an equity index for all racial and ethnic groups using four perspectives over a ten-year period: access, retention, institutional receptivity, and excellence. The report asserted that without improvements in educational attainment and status, African Americans will continue to be overrepresented in low-paying service jobs and underrepresented in higher paying jobs.

A popular pathway into four-year institutions is through the community college system since transfer is a primary mission of community colleges. In California, for example, community colleges enroll the highest numbers of African American students in the state, yet they also have the lowest rate of transfer. Between 1998 and 2002, 40\% of all California community college (CCC) students transferred. Of that group of transferred students, $41 \%$ were 
White and 5\% were African American (California Community College System Office, 2010).

To date, a major gap in the research literature on community college students is the omission of their voices on transfer experiences. While there have been numerous studies on community college transfer students, very few have included the students' perspectives on their transfer processes (Contreras, 2004; Derby \& Watson, 2006; Dougherty, 1992; Dougherty \& Reid, 2007; Gandara \& Educational Testing Service, 2005; Haro, 2004; Laanan, 2004, 2007; Rendon, 2002). And few studies have examined the transfer experiences of African American community college students from their perspectives (Jain, 2010).

This dissertation study explored the African American community college transfer student experience by amplifying the student voices. It explored their experiences with race and racism as barriers and facilitators to their successful transfer. The study revealed how African American students believed the transfer process can be improved for greater success. The following excerpt demonstrates the student voices highlighted in this study.

...I feel that as a Black man I have a responsibility to do schooling to go out and get what I can get. For our past ancestors to go through everything they went through just to make this possible, I 
think it would really be a slap in their face for us not to take advantage of these opportunities. (Mitchell int. 1/22/10, lines 60-64)

\section{Research Questions and Propositions}

This study provides student voices and personal narratives from African American students who transferred to San Francisco State University (SFSU) from colleges within the East Bay Community College District. The goals and objectives of the study were (a) to document and understand the impact of racial microaggressions from the perspective of African American students in the process of transferring; (b) to explore the facilitators and barriers to transferring for African American students; and (c) to gain a greater understanding of how interpersonal relationships affect successful transfer.

The research questions that guided this study were the following:

1. How do race and racism impact their experiences?

2. How do African American students experience the transfer process in an East Bay community college district?

3. What are the major barriers and facilitators to their successful transfer?

4. How can their stories and strategies be used to improve the transfer success of other African American students? 
In this study, I explored the proposition that faculty and staff members engage in "othermothering" that assists African American students in navigating the community college system. "Othermothering" is a connection between African American students and teachers that extends beyond the conventional relationships between students and teachers. Key elements of othermothering are (a) an understanding by the student that the person cares for them (ethic of care); (b) investment in the academic success of the African American student (cultural advancement); and (c) support within the institution (institutional guardianship). Here's an example of how othermothering manifested for one of the study participants.

I met one girl in my class, Nekeisha...she transferred a semester before us and she called us to make sure we registered for classes and did our homework. Dana and I basically buddied up because we both were transferring. She made sure I had my transcripts and actually hand-delivered them to SFSU. She is the reason why I took one math class; she told me to take this teacher because she's really good. (Marquida int. 1/13/10, lines 211-219)

Critical race theory is another theoretical tool that can increase our understanding of the role that race, racism, historical context, and narrative play in the transfer process for African American students. Because of the 
sparse research that has examined the educational experiences of African American community college students, there has been a tradition of stereotyping Black students as an at-risk and low-achieving group. Hence, this study will focus on race and racism as barriers and facilitators to successful transfer from the perspective of African American students who have transferred from a community college to a four-year university.

\section{Theoretical Framework}

This dissertation study is guided by critical race theory (CRT) incorporating the concepts of racial microaggressions and transformational resistance. In addition, othermothering is used as a conceptual framework to explain the supportive relationships that the students experienced as they progressed towards transfer. Figure 1 shows the ways racial microaggression, othermothering, and transformational resistance work like interlocking gears to assist students in transfer. 


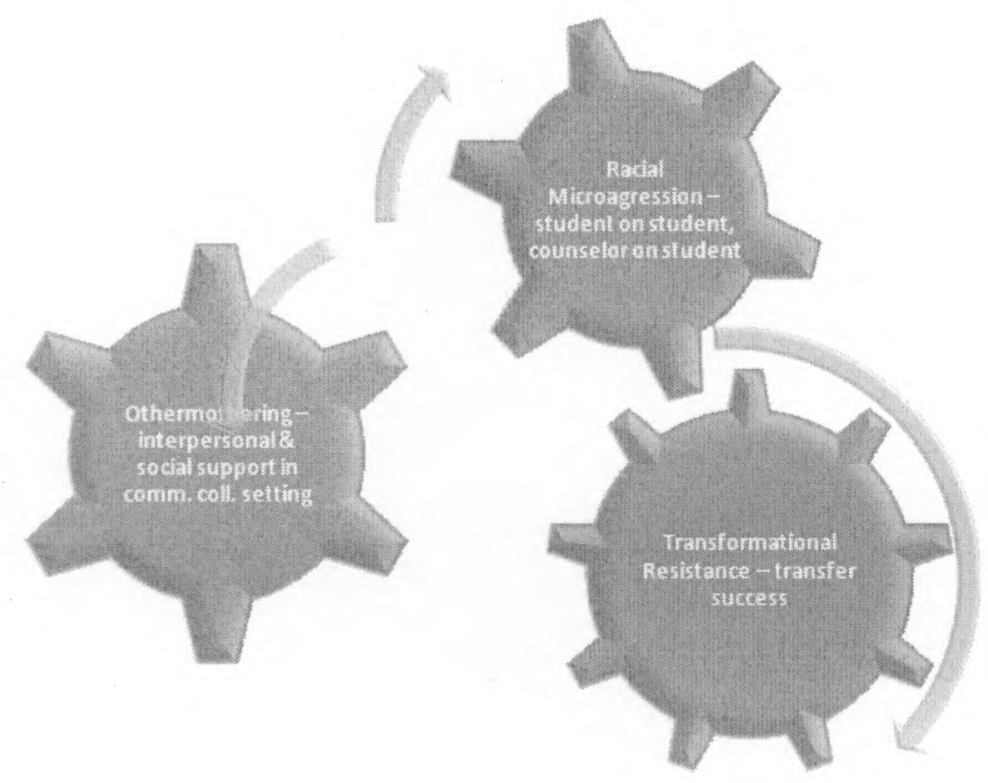

Figure 1. Theory Interaction

CRT asserts that racism is a part of American society and employs storytelling as a way to amplify experiential knowledge from a non-dominant perspective (Iverson, 2007; Ladson-Billings, 2000). CRT is a theoretical framework that can enhance our understanding of how racial inequality is (re)produced through educational policies and practices (Iverson, 2007, p. 606). CRT incorporates five tenets: a focus on race and racism, contesting dominant ideology, social justice, recognition of experiential knowledge and focus on historical context. This theory provides a mechanism to critique the omission of race and racism as well as students' experiential knowledge and notions of deficiency among African American students. 
A concept related to CRT and the kind of racism students of color experience is racial microaggressions. African American students in institutions of higher education often experience racism in the form of unconscious, subtle racism directed at African Americans (Pierce, 1970). Racial microaggressions have also been described as "daily brief and routine verbal, behavioral and environmental indignities, intentional or unintentional, that communicate hostile, derogatory or negative racial slights and insults to the target person or group" (Sue, Lin, Torino, Capodilupo \& Rivera, 2009, p. 183).

As an African American woman, I have also experienced racial microaggression. For example, former colleagues have assured me that l'll get a position I apply for because I'm a Black woman as if I weren't otherwise qualified for the position. Since I was a child, White people have told me how I speak well for a Black person, assuming other Black people don't speak well.

Another emerging theory, othermothering, may help us understand how African American community college students successfully transfer to four-year institutions. Othermothering is a specifically person-of-color framework, born out of the experiences African Americans have had with race-based slavery and inferior schools. The term refers to a concept in African American feminist literature involving a broadened relationship 
between African American students and teachers (Collins, 2000; Foster, 1993). Othermothering uplifts the Black community by having educators attend to students' social, psychological, and academic development. Othermothering also helps to prepare them for dealing with racism and White supremacy. The origins of othermothering are found in colonial slavery, elementary education, community organizing, and historically Black colleges and universities (HBCUs) in the United States. Due to the connection to slavery and the application to African Americans, racism and race are deeply embedded in this concept. This relationship goes far beyond providing technical skills or access to academic networks by providing comprehensive advising on career guidance, academic issues, and personal problems (Guffrida, 2005). An example of this expanded care may be found in Valenzuela's "authentic caring." According to Valenzuela (1999), elementary and secondary teachers are expected to demonstrate an abstract, aesthetic care to students; this relays more care for school policies than students. Alternatively, authentic caring demonstrates a reciprocal relationship between teachers and students (p. 61). This relationship demonstrates a deeper sense of caring for the students, which enables them to better learn.

Transformational resistance is another concept that helps us understand the resilience of African American transfer students. Solórzano and Bernal (2000) researched transformational resistance using a CRT and 
LatCrit theory framework. They defined transformational resistance as student actions that exhibit a critique of oppression and an aspiration for social justice. While transformational resistance has been applied to Chicana/o students, it may also be applied to other people of color who struggle with oppression such as African American students. These theories and concepts also informed this study.

\section{Positioning the Researcher}

I am a Black, Caribbean-American, gay woman who works in the East Bay Community College District as an academic manager for Disabled Students Programs and Services (DSPS). I worked as a DSPS counselor for nine years before serving as program manager. As such, I have assisted thousands of students with the transfer process. In that process I have gained a considerable amount of experiential knowledge on the challenges community college students face as they prepare to transfer. I am committed to sharing my understanding of the higher education system with the study participants. I am wholeheartedly committed to improving educational outcomes for underrepresented students in higher education and believe in supporting these study participants as they pursue their higher education.

\section{Reflections}

My interest in the topic of African American student success in 
community colleges stems in part from my personal experience as an African American researcher, disability support services counselor, and manager. My paternal grandmother was a sharecropper and maid who couldn't read or write, and my maternal grandfather was an entrepreneur, accountant, and cab driver in New York City. My father received his Master's in Business Administration at the University of Wisconsin-Madison before I could walk, and my mother completed her Associate's Degree in Interior Design soon after. I have seen firsthand how higher education can affect one's standard of living. Benefitting from my parents' higher education has always led me to encourage Black and underrepresented people to pursue higher education. For this reason, I encourage students and friends to obtain undergraduate and graduate degrees.

For the last eight years, I have worked as a disability support services counselor and manager at a community college. I have personally witnessed students' experiences with racism, anti-disability bias, sexism, homophobia, anti-transgender bias, and discouraging instructors and counselors as well as their overall struggles to remain enrolled in college. On the other hand, I have had the honor of working with African American and other underrepresented students who have successfully transferred and graduated despite the odds against them. Their challenges and success have been an inspiration to me and in my work supporting students. As a doctoral student, I have also 
benefitted from family support and the othermothering l've received from other students, my advisor, and other faculty in the program.

As a disability support services counselor and manager, I have experimented with how to encourage underrepresented students to succeed. Interventions I have employed include providing students with course and instructor recommendations; encouraging students to complete math and English requirements early in attendance; demonstrating care to students by discussing their future goals, abilities, and strengths; encouraging them with relevant stories from my educational journey; providing them with resources when they experience setbacks; and increasing support during the year before transfer for support with applications and other processes required by the four-year institution. With these efforts l've watched students maintain success over time. These experiences and perspectives provide additional dimensions to my dissertation and recommendations for community college practice.

\section{Key Terms}

Transfer is a key term used throughout the study. In the California community college system is the process of completing lower division general education and major requirements at a community college, applying to a four-year college or university, gaining acceptance, and then attending 
the chosen institution. A transfer center that is located on California Community College (CCC) campuses provides support to students navigating the transfer process as they explore four-year institutions, prepare applications, and submit transcripts to prospective institutions. Barriers pertain to the non-academic social, emotional, and interpersonal factors that discourage transfer and continued matriculation. Facilitators are the nonacademic social, emotional, and interpersonal factors that encourage transfer and matriculation. African American and Black will be used interchangeably and refer to people of African American descent.

\section{Scope of Study}

The study focuses on the facilitators and barriers of success for African American community college students who transferred. There are many important questions related to the successful transfer of African American community college students. This study explored key interpersonal connections, interactions, and individual experiences of African American students.

\section{Significance of the Study}

There is a lack of qualitative, student-centered research in the area of African American community college students. Chang (2005) recommended using qualitative research to gain a greater understanding of how students of 
color perceive and negotiate interactions with faculty. This research on the personal facilitators and barriers to transfer for African American students may assist in transforming institutional practices and policymaking.

The exploration of individual pathways, as well as institutional facilitators and barriers related to African American student transfer, told by the students, provides a unique insight on these students' experiences. This study fills a gap in the research literature pertaining to African American community college students' perspectives about transfer.

Findings from this study include information on the role of faculty, student, and staff interactions with Black students in the transfer process. Unanticipated results, such as key support from peers and transformational resistance, also emerged. These findings provide for recommendations to the East Bay Community College District regarding unique support for all transfer students.

Data generated from this study support promising directions for preparation and practice of educational leaders. Findings suggest that California community colleges are equipped to positively impact African American student transfer by prioritizing and refocusing transfer centers and counseling services. Student-derived recommendations provide community college staff, counselors, faculty, and administrators with suggestions for operationalizing othermothering in counseling and other direct-contact 
student services. Findings also suggest community colleges need to deal with racism among administrators, faculty, staff, and students to minimize the impact of racial microaggression in the classroom. Critical race pedagogy and ethnic studies courses can enhance transformational resistance and help to manage racism in the classroom.

Study findings also expand the knowledge base on racial microaggressions and educational equity issues in counseling, transfer centers, and community college classrooms. Lastly, this study provides additional information on an emerging theory, othermothering.

\section{Organization of Chapters}

This dissertation is organized into four remaining chapters. Chapter Two reviews the literature pertaining to facilitators and barriers for African American community college students. This chapter explicates CRT as a theoretical framework and its connection to the transfer process for African American students. Stemming from CRT, transformational resistance and racial microaggressions are discussed in the review of the literature.

Othermothering, an emerging theory, is another lens for analyzing relationships that facilitate transfer.

Chapter Three reviews the methodology, sample, research design, and context of the study. This study used a qualitative case study design to 
understand barriers and facilitators to transfer among African American community college students.

Chapter Four reveals key study findings, themes, and direct student responses while Chapter Five interprets the findings and relates them to concepts found in the literature as well as the research questions. Chapter Five also includes study conclusions, action recommendations, and implications for future research. 


\section{CHAPTER 2. LITERATURE REVIEW}

African American community college students in California have the lowest rate of transfer when compared to other ethnic groups. This review of the literature explores some of the obstacles Black students face in the transfer process. While the low rates of transfer are cause for concern, some Black students are transferring to four-year institutions. Consequently, the factors that facilitate transfer for African American community college students are explored as well. Considerable research focuses on African American students in four-year institutions but very little on students' actual experiences in the community college transfer process.

The literature review for this study has been guided by the following questions: How do African American students experience the transfer process in community college? What are the barriers and facilitators to successful transfer? This chapter explores the research pertaining to those questions.

Some of the barriers African American community college students experience may be associated with their race and ethnicity. Much of the literature on community college students focuses on transfer and very little considers the impact of race and racism on transfer success. This literature 
review explores existing research on challenges for community college students, California community college student demographics, African American community college students, facilitators for community college students, African American community college transfer students, racial microaggressions, critical race theory, resilient resistance, othermothering, and stereotype threat.

\section{Community College Student Challenges}

Research indicates that community college students of all ethnicities struggle to transfer to four-year institutions. These students often struggle to remain enrolled in community college, to transfer, and to persist in four-year colleges (Dougherty, 1992). Dougherty and Reid (2007) noted that community college students encounter additional challenges as they prepare to transfer to four- year institutions including lack of academic and social integration, residential housing, the transfer process, post-transfer drop out, and lower grades for upper division courses than four-year institution students.

\section{California Community College Student Demographics}

Nationally, community colleges serve most of the students of color in higher education (Provasnik \& Planty, 2008) and California community colleges serve a higher proportion of students of color than their institutional 
peers in the University of California and California State University systems (California Postsecondary Education Commission, 2010). Specifically, Black students made up $15 \%$ and Latino students made up $14 \%$ of all students enrolled in community college nationwide during the 2003-2004 academic year. After White students, these ethnic groups have the highest percentage of enrollees in community colleges. In comparison, Black students comprised only $10 \%$ and Latino students comprise $9 \%$ of all public four-year institution enrollees.

California has the largest community college system in the nation, enrolling $24 \%$ of all community college students in the United States (Community College League of California, 2010). There are over 500,000 students enrolled in community colleges in California. This system also enrolls more African American and Latino students than the California State University or University of California systems. In 2007 University of California campuses enrolled only 6,647 Black students of their 220,034 total enrollments. In the California State University System 26,019 Black students out of the total 433,017 students were enrolled. In the community colleges, 120,623 Black students out of $1,628,380$ students were enrolled. With the highest level of Black student enrollment, the possibilities of transfer seem hopeful. However, high numbers of enrollees do not necessarily translate into high numbers of African American students transferred. 
While students of color are the majority of community college enrollees in California, they are in the minority of students who transfer to four-year institutions (Jain, 2010). Of students who began taking courses at a California community college during the 2003-2004 academic year and who transferred in six years, $43 \%$ were White and $34 \%$ were African American (California Community College Chancellor's Office, 2010). Though both groups do transfer, African American students transfer at a lower rate than their White counterparts.

\section{African American College Students}

In the 1960 s, community colleges started seeing large numbers of African American students. At the same time, these colleges created vocational programs and services for non-transfer students. Remedial programs were also created so underprepared students could continue with vocational programs (Hughes, in press). These courses were essentially extra hurdles for community college students to complete as they journeyed toward bachelor degree completion. Like African American students at community colleges, Black students at historically Black colleges and universities struggled with being academically underprepared. See Appendix A for a table comparing research literature on African American transfer students. 
Hughes (in press) noted HBCUs traditionally served African American students from the most underperforming schools throughout the nation. Historically Black colleges and universities were able to graduate students from these schools. He observed community colleges are often not ready for academically underprepared students yet they have not significantly changed how they serve this population for the last 40 years. According to Hughes, HBCUs have enrolled underprepared students since their creation and have developed strategies for support. He asserted that community colleges struggling to serve underprepared students could learn how to better serve the population by investigating how HBCUs respond to similar challenges.

Other researchers investigated African American college students in addition to Hughes (in press). Some of the factors related to African American students, as a population, include mentoring, attrition, and the impact of the multiple missions of community colleges and are discussed both in Appendix B and below.

Feist-Price (2001) considered African American faculty mentoring at predominantly White institutions. She wrote about issues associated with mentoring relationships from a general and personal perspective, specifically the difficulty that African American faculty experience in satisfying institutional expectations and personal commitments to mentor students. According to Feist-Price, African American students enter college socially, 
educationally, and economically disadvantaged; and receiving mentoring from African American faculty can significantly enhance their ability to navigate and graduate.

Once African American students have matriculated into four-year colleges, other challenges emerge. Dougherty (1992) identified challenges to transfer and persistence at four-year institutions for community college students, and Dougherty and Reid (2007) considered the impact of socioeconomic background on transfer. Dougherty found community college students are challenged with remaining enrolled, especially considering higher dropout rates for non-White students. He found they also struggle with the community college's inability to integrate students into the academic and social life of the college. Dougherty (1992) also noted moving to a new institution, inadequate transfer advice, and being drawn into occupational programs as challenges that face transfer students.

\section{Facilitators for Community College Transfer Students}

Considering the challenges that face all community college students in general and African American community college students in particular, it is helpful to review the following studies, which described interventions that may support this population. McGrath and Tobia (2008) wrote about the need for institutions "to widen the frame of analysis to include social and institutional contexts that influence student and staff behavior" (p. 42). They 
recommended the institution of learning communities, career mentoring, collaborative research projects, and authentic problem-based learning activities to enhance retention.

Glenn (2004) discussed freshman orientation, advising, and understanding faculty members as interventions that support African American males in higher education. Other research supporting African American community college students suggested that positive faculty connections, advising, parental involvement, and institutionalizing beneficial existing support programs such as MESA are important for academic success. Researchers have concluded that these programs have contributed to the retention, transfer, and graduation of African American students in community colleges (Haro, 2004). Interaction between faculty and students is an important component to student success and transfer.

Other researchers investigated the impact of African American community college student relationships with faculty on the students. Volkwein, King, and Terenzini (1986) found students' perceptions about the quality and strength of their relationship with faculty were significantly associated with two measures of intellectual growth. Involvement with faculty inside and outside the classroom was deemed important for the development of intellectual skills in community college transfer students (p. 426). 


\section{African American Community College Transfer Students}

To date, a major gap in the research literature on community college students is the omission of their voices regarding transfer. While there have been numerous studies on community college transfer students, very few include the students' perspective on the transfer experience. The following section discusses some of the studies on facilitators of success for African American community college students that do not explicitly include the student perspective.

Derby and Watson (2006) investigated orientation programs and African American student retention within community colleges. They suggested that community college professionals play an important role in the retention of minority students and should participate in self-reflection to reveal personal biases that may perpetuate barriers to that retention. While the study was well designed, it did not include a student perspective.

Greene, Marti, and McClenney (2008) investigated the connection between minority status, student engagement, and academic outcomes in two-year colleges. The researchers found that bridge-programs, welcome centers, required academic advising, and participation in a student success course assisted minority student success at these colleges but their research also did not include actual students' voices. Museus, Nichols, and Lambert (2008) conducted a study on the effect of campus racial climate on the rate 
of degree completion; they suggested that faculty make conscious efforts to structure classrooms to promote interactions that combat cultural and racial barriers with the goal of improving the climate within their classrooms.

While these studies focused on ways to support African American community college students, they were not written from a student perspective. Students can provide key information on their transfer experiences that can help faculty, staff, and administrators better support students. For this reason, it is important to include students' perspectives in the literature on African American community college transfer students.

One study examined the transfer experiences of community college student leaders who were women of color from their perspectives. In addition to providing the students' perspectives, the study also dealt with racism within California community colleges. While race and ethnicity may be mentioned in community college literature, racism is rarely discussed. After the California ballot initiative proposition 209 passed in 1996, there was a marked decline in the discussion of race and consequently racism in public institutions of higher education including the community college system. Proposition 209 amended the California constitution to prohibit public institutions from considering race, sex, and ethnicity. 
Jain (2010) conducted a qualitative study on women of color student leaders and the rate of transfer. She found racism and sexism were alive and well in California community college classrooms and that CRT provides an excellent lens for the critical racialized analysis of transfer. The following section discusses racial microaggressions, CRT, transformational resistance, stereotype threat, and othermothering.

\section{Racial Microaggressions}

African American students in institutions of higher education often experience racism in the form of racial microaggressions, the unconscious, subtle forms of racism directed at African Americans (Pierce, 1970). These have also been described as the "daily brief and routine verbal, behavioral and environmental indignities, intentional or unintentional, that communicate hostile, derogatory or negative racial slights and insults to the target person or group" (Sue et al., 2009, p. 183). According to Sue et al. (2009), racial microaggressions manifest in three ways: microassaults, microinsults, and microinvalidations.

Microassaults are intentional and overt. An example would be the recent hanging of a noose in the library at the University California San Diego on February 26, 2010. The sight of a hanging noose is often associated with the lynching of Black people throughout the United States. The noose was 
intentionally hung after students protested a racist-themed Compton Cookout hosted by a fraternity a few days earlier.

According to Sue, Nadal, Capodilupo, Lin, Torino, et al. (2008), microinsults are the rude verbal, nonverbal, or environmental actions that convey insensitivity and demean a person's racial identity or heritage. An example of a microinsult might be telling an African American that he or she is a tribute to his or her race, implying that his or her race is inferior with the exception of the person receiving the microinsult.

Microinvalidations are defined by Sue et al. (2008) as actions that exclude, negate, or nullify the psychological thoughts, feelings, or experiences of people of color. Telling an African American, Asian American, or Latino that he or she speaks well would exemplify microinvalidation. During her March 8, 2010 television show, Wendy Williams, a popular African American talk show host, recently mentioned it is not a compliment to tell African Americans that they speak well. She asserted it is an insult to tell African Americans that they speak well because it implies the group doesn't or shouldn't speak well.

Researchers have delineated the following consequences of racial microaggressions on people of color: significant negative impact on mental health (Sue, D. W., Nadal, K. L., Capodilupo, C. M., Lin, A. I., Torino, G. C., \& Rivera, D. P. (2008); a hostile and invalidating campus climate (Solórzano, 
Ceja, \& Yosso, 2000) and perpetuation of stereotype threat (Steele, 2009). Microaggressions reflect an unwitting paradigm of White supremacy that directly invalidates the racial reality of Black Americans. Racial microaggressions in academia impact the academic and social life of African American students. While there have been studies on racial microaggressions and various groups of people of color, very few of these pertain to community college students of color.

\section{Theoretical Overview}

Critical race theory has been used extensively to examine secondary and postsecondary education but it has not been used as widely to examine community college research or practices (Jain, 2010). The application of CRT to community colleges allows us to understand transfer as a racialized occurrence. Since Black students transfer at a slower rate than White students, a lack of parity exists between the two groups. Because CRT focuses on race, racism, and equity, the lack of equity in transfer rates between African American and White students can be explored. CRT also creates space for the narrative experiences of African American community college students who are likely to experience transfer differently from White students. While the requirements to transfer are the same for both groups, the institutional and societal issues the two groups of students experience 
while transferring are different. White students do not transfer with a lifetime of experiences with institutional and societal racism or racial microaggressions as African American students often accumulate. These differences alone exist due to race, ethnicity, and a history of oppression in the United States.

CRT asserts that racism is a part of American society and employs the use of storytelling as a way to amplify experiential knowledge and stories of oppressed people (Iverson, 2007; Ladson-Billings, 2000). CRT incorporates the following tenets: a focus on race and racism, interest convergence, the historical context of colonialism, racial and social justice, and a preference for the experiential narratives of oppressed people.

Othermothering was discussed in African American feminist literature. (Collins, 2000; Foster, 1993). It works to strengthen the Black community by having educators provide social, psychological, and academic development to students and preparing them for racism and white supremacy. Othermothering occurred among African Americans during American slavery, elementary education, community organizing, and at historically Black colleges and universities. Racism and race are deeply embedded in this concept. Othermothering goes beyond providing technical skills or access to academic networks by providing comprehensive advising on career guidance, academic issues, and personal problems (Guffrida, 2005). 
Authentic caring is another example of othermothering. According to Valenzuela (1999), elementary and secondary teachers are expected to care more for school policies than students. Alternatively, authentic caring reveals a reciprocal relationship between teachers and students (p. 61). This relationship expresses a deeper sense of caring to the students which facilitates their learning.

Othermothering is originates with African Americans who experienced race-based slavery and inferior schools. Othermothering is discussed in more detail below.

\section{Critical Race Theory}

CRT traces its academic origins to critical legal studies in the 1970s (Bell, 1992; Crenshaw, Gotanda, Peller, \& Thomas, 1995). Scholars and activists created CRT to transform the relationship between race, racism, and power in post-civil rights America (Ladson-Billings, 1998). CRT is concerned with race and racism, racialization, and the relationship between race and property rights as well as the intersection of class, gender, ability, and sexuality (Delgado \& Stefancic, 2001; Solórzano, 1998; Solórzano \& Yosso, 2002; Taylor, Gillborn, \& Ladson-Billings, 2009). The following sections briefly discuss the tenets of CRT. 
CRT in education has been used to bring attention to the inequity that people of color experience in schools (Ladson-Billings \& Tate, 1995; Solórzano, 1998). Some of the tenets of CRT include society's acceptance of race and racism as ordinary, interest convergence, understanding the historic effects of European colonialism, and the preference of the narratives of oppressed people over the "objective" opinions of whites (Taylor, 2009). Because CRT accepts the existence of race and racism in society, it is important to briefly discuss race and racism as they relate to CRT.

Banks (1993) characterized race as socially constructed and used to differentiate racial groups and to show superiority of one racial group over another. Lorde (1992) defined racism as the belief in the superiority of one race over all others and the right to dominance (p. 496). Taylor, Gillborn, and Ladson-Billings (2009) discussed racism as a global system of white supremacy, a political system with a power structure of formal and informal rule, privilege, socioeconomic advantages and wealth and power opportunities (p. 4). The encompassing nature of racism makes it hard to be seen or recognized by its beneficiaries. These authors noted the apparent lack of interest that White people have in understanding widespread racial inequality as evidenced by discrimination in housing, hiring, criminal sentencing, education, and lending. This lack of understanding leads to a false belief that oppression no longer exists. CRT asserts that incidents of 
oppression are linked to larger historical and institutional White hegemony (Taylor et al., 2009). Just as privileged people have difficulty recognizing the privilege they have in U.S. society, community colleges also struggle to recognize the impact of race and racism on students and staff.

Another tenet of critical race theory is interest convergence. Bell's theory of interest convergence (1980) occurs when the interests of Blacks gaining racial equality are accommodated when they have converged with the interests of powerful Whites. The Brown v. Board of Education (1954) decision is an example of interest convergence. In the period leading up to the decision, the U.S. Justice Department was concerned with the country's image. Consequently, they filed an amicus brief in the case stating that desegregation was in the nation's interest due to foreign policy concerns. The U.S. was positioning itself as the leading nation against communism and worried about stories on the Klu Klux Klan, lynching Black people, and the deplorable conditions of African American sharecroppers that were broadcast in the Soviet Union, India, and China. Brown v. the Board of Education provided an opportunity to improve U.S. public relations. While it appeared that the U.S. government supported desegregation and African Americans' plight overall, in reality the segregation of schools did not end. Without enforcement provisions, Black schools were shut down and many Black 
teachers were left unemployed. The loss of Black schools was devastating for the students as well as teachers and staff.

CRT grounds itself in a specific historical context. This context recognizes that the U.S. political, legal, and educational system is founded on White people's absolute rights to property and capital. Historically, American Indians provided land while African Americans provided enslaved and immigrant laborers to deliver those rights to Whites. However, the systems mentioned above did not retain the realities of American Indian and African American property and labor provision in their collective memory. This lack of recollection reveals a blatant ignorance of the country's racist past. This same ignorance causes a lack of connection between the achievement gap of children of color and Whites in education today with the historical context of inequality from the previous decades fueling that gap.

CRT aims to shift the mainstream gaze to historically underrepresented viewpoints using narrative and positionality. CRT challenges the viewpoint of Whites as the standard by emphasizing the racialized experiences of people of color. In the use of the narrative, CRT connects the current social, legal, and educational inequities to prior explicit practices of racial exclusion. These narratives include storytelling, autobiography, and parable and use them to challenge social constructions of race (Taylor, 2009, p. 8). This challenging occurs in the way CRT 
embraces the negative experiences people have had with racism, validates them, and openly acknowledges the knower's perception of truth, fairness, and justice. Thus, positionality identifies the frame of reference from which researchers and practitioners present their data, interpretation, and analysis.

Social justice is another important component of CRT. Embracing social justice, CRT critiques liberalism and the belief that change must come slowly. CRT asserts that fighting racism, sexism, homophobia, and class discrimination requires the kinds of sweeping changes that are possible through social justice.

In addition to understanding some of the challenges in African American community college retention, institutions are also challenged with understanding how racism impacts retention as well. Iverson (2007) found that CRT analysis of assumptions embedded in existing practices may begin a process of naming and dismantling racism. CRT provides a theoretical framework for understanding how racial inequality may be perpetuated in institutional practices making it even harder for African American students to successfully transfer. In addition to racial microaggressions, other racially oriented phenomena occur in educational settings for African American students. The literature documents the resistance that students engage to work against oppressive structures. The following section discusses transformational resistance. 


\section{Transformational and Resilient Resistance}

As mentioned above, resistance is also represented in the literature with articles from CRT scholars such as Solórzano and Bernal (2000) and Yosso (2000). Solórzano and Bernal (2000) examined transformational resistance using a critical race and LatCrit theory framework, and they focused on key events in Chicana and Chicano student history in the Los Angeles area. The authors noted that resistance theories illustrate how individuals balance fighting oppressive structures while making sense of the representations of their own actions. They defined transformational resistance as student actions that reveal a critique of oppression and a desire for social justice.

Yosso (2000) also discussed resistance in her article critiquing the media for negative representations of Chicanas and Chicanos using a CRT and LatCrit lens. She coined the term "proving them wrong", which refers to "students who confront negative portrayals of Chicanas/os and are motivated by the negative images, ideas and are driven to navigate through the educational system for themselves and other Chicanas/os." (p. 109). Yosso (2000) also discussed resilient resistance, "succeeding through the educational pipeline as a strategic response to visual microaggressions" ( $p$. 180). While transformational resistance, proving them wrong, and resilient 
resistance have been applied to Chicana/o students, these concepts may also be applied to other people of color.

\section{Stereotype Threat}

African American community college students most likely experience stereotype threat or the fear of being reduced to a bad stereotype. African American students in institutions of higher education often experience stereotype threat. According to Steele (2009), stereotype threat is the social, psychological threat that arises when one is in a situation or doing something for which a negative stereotype about one's group applies. It threatens one with being negatively stereotyped, judged or treated stereotypically or with the prospect of confirming the stereotype (p. 163). According to Steele (2009) wise schooling assures students that they will not be held to negative stereotypes. This type of schooling would enable students to perform more freely without the threat of being associated with negative stereotypes. The term wise comes from gay men and lesbians in the 1950s. Heterosexuals who understood gay men's and lesbians' full humanity, not just the negative stigma ascribed to non-heterosexual people, were considered wise. Steele (2009) applied the term to schooling since it would be schooling that also recognized the full capacity of students instead of reducing them to the negative stereotype of their group. Wise strategies such as optimistic 
teacher-student relationships challenge instead of remediation and stressing the expandability of intelligence all work to reduce stereotype threat.

Since existing stereotypes impact ability-stigmatized students worried that educators will doubt their abilities, positive teacher-student relationships work to diffuse that concern. Critical feedback coupled with optimism about the students' potential was also motivating for African American students (Steele, 2009). Challenging work expresses respect for student potential and demonstrates that the student is not viewed through an ability-deficient and demeaning lens. Remedial work reinforces the possibility that the student is being viewed stereotypically and may undermine his or her performance. Challenging students at their level without overwhelming them can also reduce stereotype threat. Thirdly, stressing the expandability of intelligence assists in shutting down the negative-ability stereotypes that may be associated with a group as a fixed limitation. Stressing the incremental expansion of intelligence may deflect this stereotype.

While CRT is an excellent theoretical tool for critiquing race, racism, the relationship between race and property, and the racialization of the transfer experience, another tool is necessary to help us understand the success that African American community college students have experienced. An emerging theoretical framework, othermothering, 
supplements CRT by helping us understand how African American community college students successfully transfer to four-year institutions.

\section{Othermothering}

Othermothering developed during the racist institution of slavery when enslaved African mothers, owned as the property of Whites, were separated from their children, which required them to be raised by othermothers. Othermothering assisted in the survival of African Americans during slavery and beyond. According to Collins (1991) and Loder (2005), "othermothers" have been defined as the African American women who work on behalf of the Black community by expressing ethics of caring and personal accountability that embrace conceptions of transformative power and mutuality (Loder, 2005 p. 132). Othermothering stems from the tradition of matrilineal care giving associated with African American communities based on historic necessities from the separation of families during slavery (Hirt, Amelink, McFeeters, \& Strayhorn, 2008).

Case (1997) and Foster (1993) noted three elements that ground othermothering: the manner in which the underlying ethic of care is transmitted; cultural advancement, and institutional guardianship. The ethic of care is defined as an ongoing, attentive, and emotional response to one's engagement with students. This concept extends the idea of familial 
nurturing to interactions with students within educational institutions. Cultural advancement is carried out as individuals receive advice, mentoring, and sometimes parenting from more experienced representatives of the African American Community.

While othermothering originated in the Black community, it is not limited to that community. Other people of color may also provide othermothering; however, othermothering is most often associated with African Americans. Othermothering does not rely solely on the presence of other African Americans although they can enhance othermothering. As its name suggests, othermothering goes above and beyond typical mentoring since it incorporates fortification of an oppressed group, elements of advancement, and greater personal support with fewer boundaries than typical mentoring. The authors, Case (1997) and Foster (1993), asserted that demonstrating a vested interest in individuals outside an immediate family unit encourages development and allows transmission of the African American culture. Lastly, institutional guardianship recognizes schools as the primary setting where othermothering takes place and as such the repositories of cultural and intellectual capital (Hirt et al., 2008).

Hirt et. al, (2008) found men and women engaged in othermothering equally. Professionals at historically Black colleges and universities should be willing to engage in othermothering. Student affairs professionals at 
majority serving institutions may be able to strengthen their relationships with students if they treat them as family.

Similar to Duncan-Andrade's (2009) assertion that hope and sacrifice are required for urban educators, othermothering also requires. This sacrifice also signals the sincerity of the othermother's intent. Case (1997) concluded that Black student academic achievement is enhanced when educators implement an othermothering approach. This may be particularly relevant for community college practitioners, struggling to better support underrepresented students.

Guffrida (2005) studied the ways in which student-centered faculty went above and beyond their roles to assist students with academic, career, and personal issues and connected those results to the African American educational and community tradition of othermothering. Over time these participant's actions impacted the culture of educational institutions as a whole, and both men and women began forming supportive relationships with students (Foster, 1993).

Othermothering is also described as the practice of educating and socializing children in Black culture to uplift the Black community and assist them in resisting White domination (Guffrida, 2005). Othermothering was passed on to teachers through their own elementary and secondary education in segregated schools and directly in teacher preparation 
programs at HBCUs during the first half of the twentieth century. Guffrida (2005) noted that trainees learned it was their moral duty to uplift the Black community by attending to students' social and psychological development as well as their academic issues. Guffrida (2005) found that White faculty could not fulfill all roles that Black faculty could provide but they could support students by incorporating more diversity into their curricula and by striving to reduce their stereotypical views and behaviors. Guffrida also called for future studies conducted by African American researchers so more detailed and diverse participant perspectives could emerge. Figure 2 below visually shows how CRT and othermothering intersect.

\section{Intersection of CRT and Othermothering}
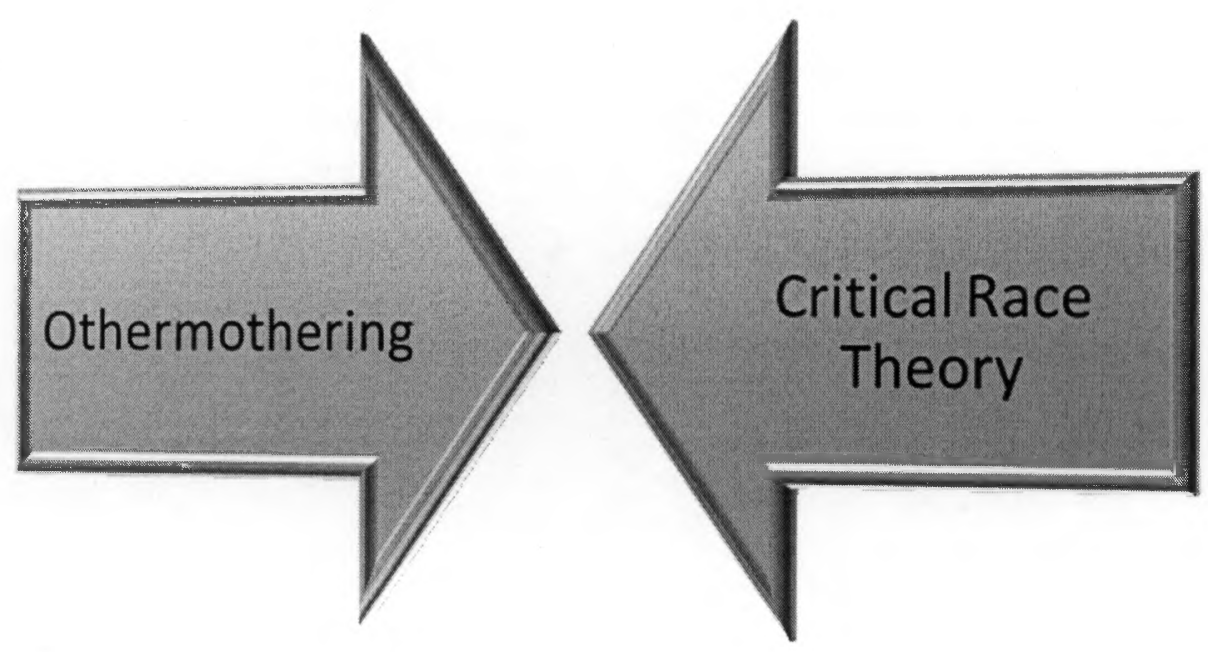

Figure 2. Convergence of Othermothering and Critical Race Theory 
CRT and Othermothering are frameworks that provide a venue to better understand and uplift African American community college transfer students. While CRT acknowledges racism, property rights, and the historical inequities that led to the achievement gap between African Americans and White students, othermothering transcends the legacy of racism and property rights in the U.S. to help African Americans overcome these barriers anddespite them-progress educationally.

CRT accepts the racist confiscation of labor and property that allowed Whites to flourish at the expense of African Americans in the United States. The concept extended to education and became a way for African American students to progress. The personal, social, and psychological support for life, educational pursuits, and assistance in coping with racism gained from othermothering has helped students and educators in higher education. Optimistic teacher-student relationships also occur in othermothering and are geared toward affirming the potential of students in adult relationships. This role of othermothering in supporting the community and combating racism is complimentary to the social justice tenet of CRT. Othermothering seems to operate outside the dominant norm, working to create the positive outcomes that society does not allow for Blacks. 
In conclusion, very little literature pertains to the racial and lived experiences of African American community college transfer students and in their own voices. While the commonplace interventions of orientation, academic advising, specialized programs, and mentoring are all somewhat effective and documented in the literature, the application of CRT and othermothering to African American community college transfer students has not been documented. This study adds to the research literature by presenting the voices of African American community college transfer students and increasing the understanding of othermothering as an emerging theory. 


\section{CHAPTER 3. METHODOLOGY}

\section{Overview}

This chapter discusses the research design, context, participants, methodology, data collection, and data analysis for the study. The purpose of this study was three-fold. The goals and objectives were (a) to explore the facilitators and barriers to transfer for African American students; (b) to gain a greater understanding of how interpersonal relationships affect successful transfer; and (c) to document and understand the impact of racial microaggressions from the perspective of African American students in the process of transferring. This is a study of student voice using in-depth interviewing and narrative analysis. Study participants wrote and discussed challenges and support they received while preparing to transfer from a Northern California community college. Participants were also asked about the perceived impact of their race and ethnicity on the transfer preparation process. By documenting sources of support and challenges for these students, as well as their recommendations,- findings from this study may serve as a resource for improving institutional support for African American community college transfer students. 


\section{Research Design}

This dissertation employed a qualitative case study research design that included analysis of narrative products (Riessmann, 1993) as a method of data interpretation. This allowed me to extract themes from the stories of African American community college students who transferred to San Francisco State University. Narrative research permits the researcher to collect data through participants' telling of personal experience (Elliott, 2005). This type of research is used when the accounts of individuals can provide distinctive insight into an issue being studied. In analysis of narrative data, the researcher works to gather reflections of past events through interviews or observations and extracts themes to create an understanding of a larger question. Key characteristics of narrative include the use of context in telling a story, a focus on the individual, and an emphasis on the construction of personal accounts based on the information collected from interviews (Creswell, 2005). Utilizing a qualitative research approach in this dissertation allows the students to make a personal connection to the research process and inform the findings of the study.

By implementing this type of qualitative research, the students' expertise on successful transfer is shared, and they provide the direction on the improvement of transfer preparation. Additionally, this research method can empower students to persist in higher education by exchanging their 
insights on transfer preparation and engagement in doctoral research for concrete support in the form of scholarship resources and tailored advice for surviving the San Francisco State University (SFSU) experience. Once the themes are analyzed, they can serve as a detailed method for collecting and examining information (Bryant, 2006).

Critical race theory is one of the theoretical underpinnings of this dissertation and centralizes the use of experiential knowledge that may not be included in the dominant ideology. Community college students of African American descent most likely experience some form of racism while attending college, but discussion of racism is missing from the majority of research on community college transfer students. This qualitative research guided by CRT provides a space for narratives on the intersection of race, ethnicity, and racism in transfer preparation. In addition to CRT, othermothering, an emerging theory (Case, 1997; Hirt et al.,2008; Loder, 2005), also guided this research. Othermothering provides support and advancement to African American students and is most utilized at historically Black colleges and universities. In this dissertation, CRT provided a theoretical framework for analyzing both historical and structural racism in higher education, and more specifically in community colleges. Further, othermothering is a theoretical construct that is helpful for explaining participants' successful transfer experiences despite the odds against them. 
In order to understand students' experiences from their perspective and in their own voice, it is necessary to use qualitative methods of data collection. This dissertation used a qualitative case study approach (Collins, Onwuegbuzie, \& Jiao, 2007). As mentioned above, qualitative research allows for the collection of experiential knowledge. Chang (2005) recommended using qualitative research to gain a greater understanding of how students of color perceive and negotiate interactions with faculty. This qualitative research design included in-depth, semi-structured personal interviews as well as the collection of written survival narratives from participants. In some aspects this study is also an action research study since the interview questions also served as an intervention that enabled participants to get more information on continuing in higher education.

\section{Role of the Researcher}

I am a Black, Caribbean-American, gay woman who works in the East Bay Community College District as an academic manager for Disabled Students Programs and Services (DSPS). I worked as a DSPS counselor for nine years and program manager for two years. As such, I have assisted many students with transfer. Working with these students, I have developed experiential knowledge on the challenges community college students face during transfer. 
In terms of my educational experiences, I have attended predominantly White and also predominantly Black and Latino institutions of higher education; these experiences have given me considerable insight into the differences between being the only person of color in the classroom and being one of several people of color in the classroom. As the sole person of color in class, I experienced self-consciousness, racial microaggressions, and overt racism as well as frustration and isolation from the lack of shared experiences. These experiences sometimes led to being hyper-vigilant in those classes as my defenses were heightened. In contrast, being one of several people of color in the classroom allowed me to lower my defensive shield against racism, feel much less self-conscious, and develop supportive connections to peers.

Having members of my nuclear family who attended a community college, a historically Black university, and an out-of-state public university, I am not the first generation of my family to attend higher education. Therefore, my ability to analyze that experience may be limited. To that end I recognize I am privileged and consequently committed to sharing my understanding of the higher education system with the study participants. I am wholeheartedly committed to improving educational outcomes for underrepresented students in higher education and believe in supporting these study participants as they pursue their higher education. 


\section{Proposition and Research Questions}

The proposition that guides data analysis is that faculty and staff members engage in othermothering, which assists African American students in navigating the community college.

African American students encounter unique challenges within the community college system, but there are gaps in our understanding of their educational experiences. These community college students are sometimes stereotyped as at-risk and low-achieving in academia. Hence, this study of the transfer experiences and support received by African American students within the California community college system seeks to contribute to a multidimensional perspective on these students' experiences in higher education. The main research questions guiding this dissertation are the following:

1. How do African American students experience the transfer process in East Bay Community College District?

2. What are the major barriers and facilitators to their successful transfer?

3. How do race and racism impact their experiences?

4. How can their stories and strategies be used to improve the transfer success of other African American students?

I used several follow-up questions in an effort to create a comfortable environment. Additional conversational questions were asked to elicit further 
elaboration on a particular response or to provide clarity. (See the Research Question table in Appendix B.)

\section{Context}

This dissertation study explored the experiences of African American students formerly enrolled at three Northern California community colleges in the same district. The names of the colleges, the district, and the towns have been changed to protect the confidentiality of participants. The participants are students who transferred from College One, College Two, or College Three. Each college is publicly supported and part of the East Bay Community College District, which serves over one million people. (See Appendix $\mathrm{C}$ for a comparison of the colleges.)

College One is located 20 miles east of the University of California Berkeley with an additional campus in the Dublin area that serves approximately 5,000 students in the southern part of the county. The college opened in 1949 and is situated on 110 acres of rolling hills near a well-known East Bay mountain. College One serves 24,000 students and has one of the highest rates of transfer to the University of California and California State University higher education systems. College One employs over 1100 faculty and staff and offers over 1000 courses annually. There are 21 counselors, yielding a 1143:1 student-to-counselor ratio. According to a fact book from 
College One, $63 \%$ of all faculty are White and $60 \%$ of all employees are White while $4.5 \%$ of all faculty, staff, and managers are African American. College One has a small, recently developed program called Ujima, to support African American students at the college; $4.7 \%$ of all students are African American.

College Two opened in 1974, is situated on 120 acres, has a campus near Oakley, and serves approximately 10,000 students in the eastern part of East Bay County. During the fall semester of 2008, 779 courses were offered. Of the 484 employees, $72 \%$ are faculty, $23 \%$ are classified staff, and $5 \%$ are managers; $59 \%$ of these employees are White, $10 \%$ are Latino, and 9\% are African American. College Two has 11 counselors for a student-tocounselor ratio of 909:1. This college has been designated a Hispanic Serving Institution since over $25 \%$ of the student population is Latino and has an Umoja program to assist African American students in degree completion and transfer. Of the students, $15 \%$ are African American.

College Three is located in the western part of East Bay County situated on 83 acres of land with views of San Pedro Bay. The college opened in 1950 and serves approximately 8,600 students. Of the students, $27 \%$ are African American, while of the employees, $46 \%$ are White and $21 \%$ are African American. There are 12 counselors and a student-to-counselor ratio of 716:1. College Three has an African American Student Mentor 
program to assist Latino and African American students with the transfer process.

San Francisco State University (SFSU) is situated on 142 acres in the southwestern part of San Francisco. There are two campuses located in downtown San Francisco and the Sierra Nevada foothills and a center in Marin County. The college was founded in 1899 as a two-year teacher training college called the San Francisco State Normal School. Currently SFSU serves 30,000 students; most are undergraduates and $6.5 \%$ of them are African American. SFSU employs over 1700 faculty and 2000 staff members. African Americans comprise $4.6 \%$ of all faculty members. Bachelor degrees are offered in 115 specialization areas, Master's degrees are offered in 95 specialization areas as well as two doctoral level programs in 8 colleges. The study was conducted in January 2010 at College One, College Two, and San Francisco State University (SFSU). (See Appendix C for a demographic comparison for the institutions.)

\section{Participant Selection}

Participants rapidly responded to the email inviting them to participate in the study. They were very interested in sharing their stories to support other African American community college students in the transfer pipeline. The accessible population consisted of approximately 57 African Americans 
who attended a community college in the East Bay Community College District and transferred to San Francisco State University in the spring or fall of 2009. For the purposes of this study, Black, African American, and African American descent are used interchangeably. In the United States, most African Americans are aware of the one-drop rule that identifies African American heritage. The One-Drop Rule designates anyone with any amount of African/Black blood as Black (Cruz-Janzen, 2002). Due in large part to racism, in the United States African Americans are defined by any percentage of African American blood. For this reason, multiracial students of African American descent are included in this study.

The sample included 12 students. Key inclusion criterion was the following: adult students of African American descent who transferred from College One, College Two, or College Three to SFSU during either the spring or fall 2009 semester. In the spring 2009 semester, 26 African American students from East Bay Community College District transferred to SFSU and in the Fall 2009 there were 31 students. The SFSU Research Office provided me with the contact information for students who met the inclusion criterion. I contacted the group via email and interviewed the first 11 volunteers. One participant was purposively recommended by another participant due to the assistance the participant received from his or her peers regarding transfer so 12 students were interviewed. There were eleven 
female and one male participant; nine students attended College Three, two students attended College One, and one student attended College Two. (See Figure 3 below.)

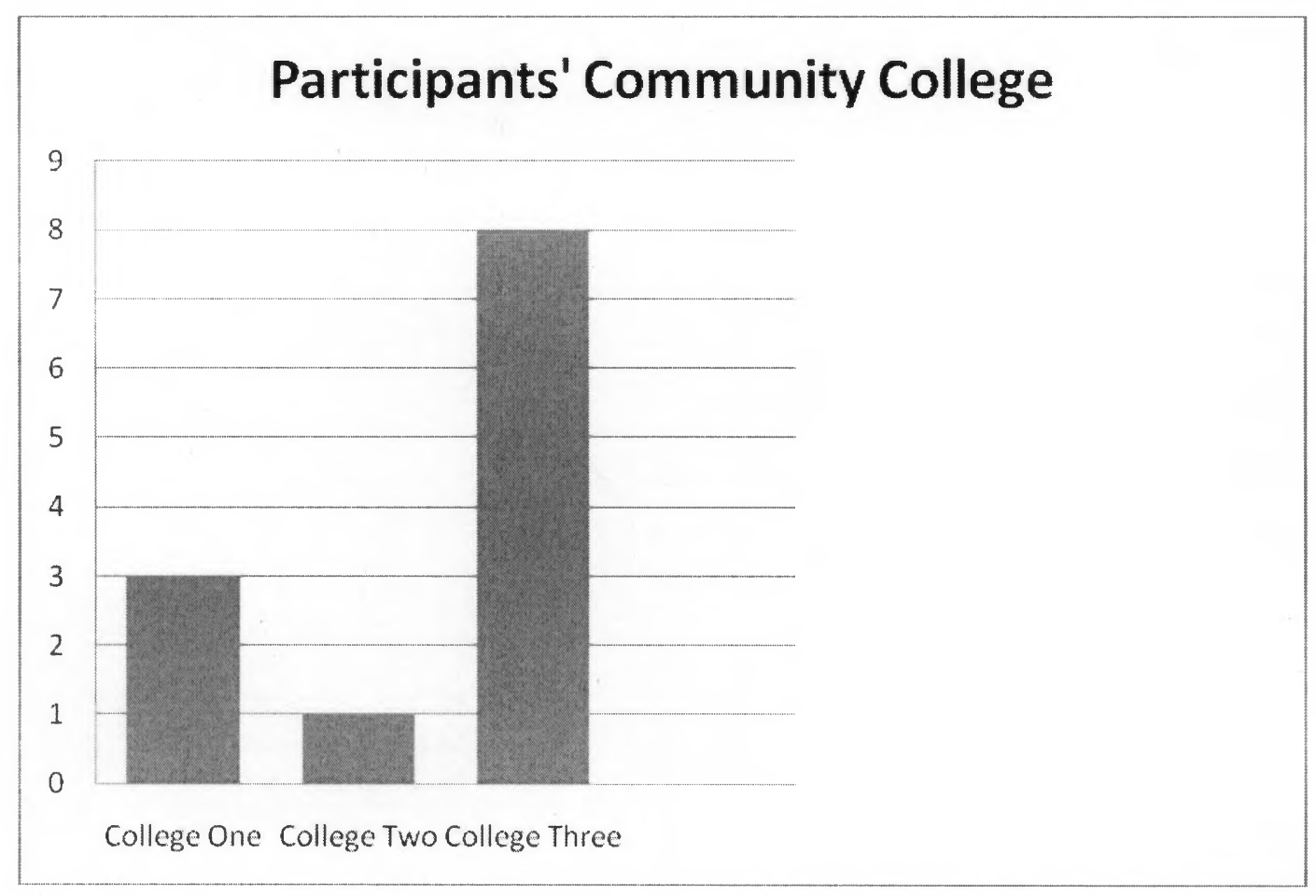

Figure 3. Participant Community College Attendance

All the students attend college full time. The average age of the participants was 26 years. Nine of the students were the first in their families to attend college. The participants' majors included Communications, Business Finance, English, Criminal Justice, Psychology, Family and 
Consumer Science, Sociology, Kinesiology, and Japanese. (See Figures 4 and 5 below.)

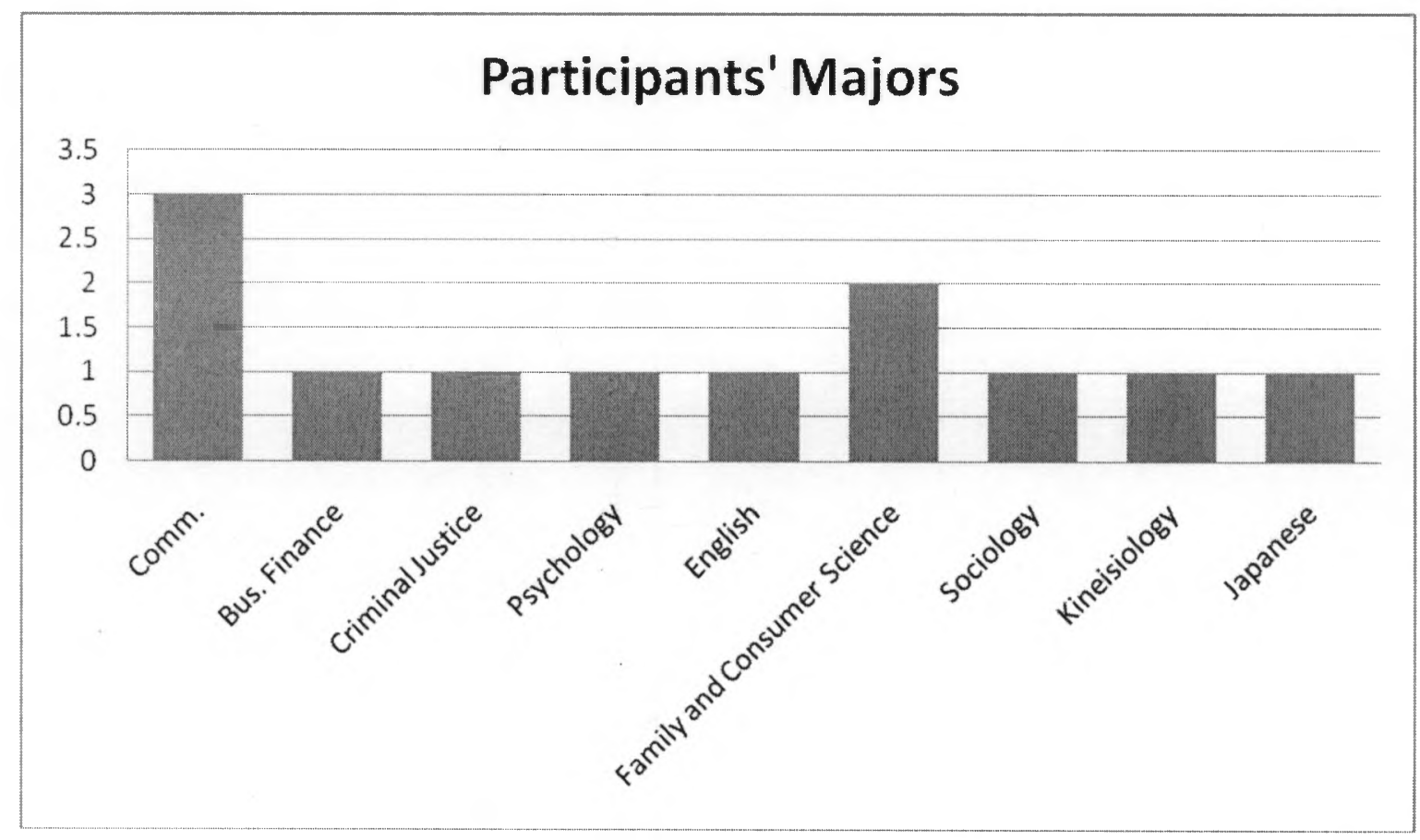

Figure 4. Participants' Majors 


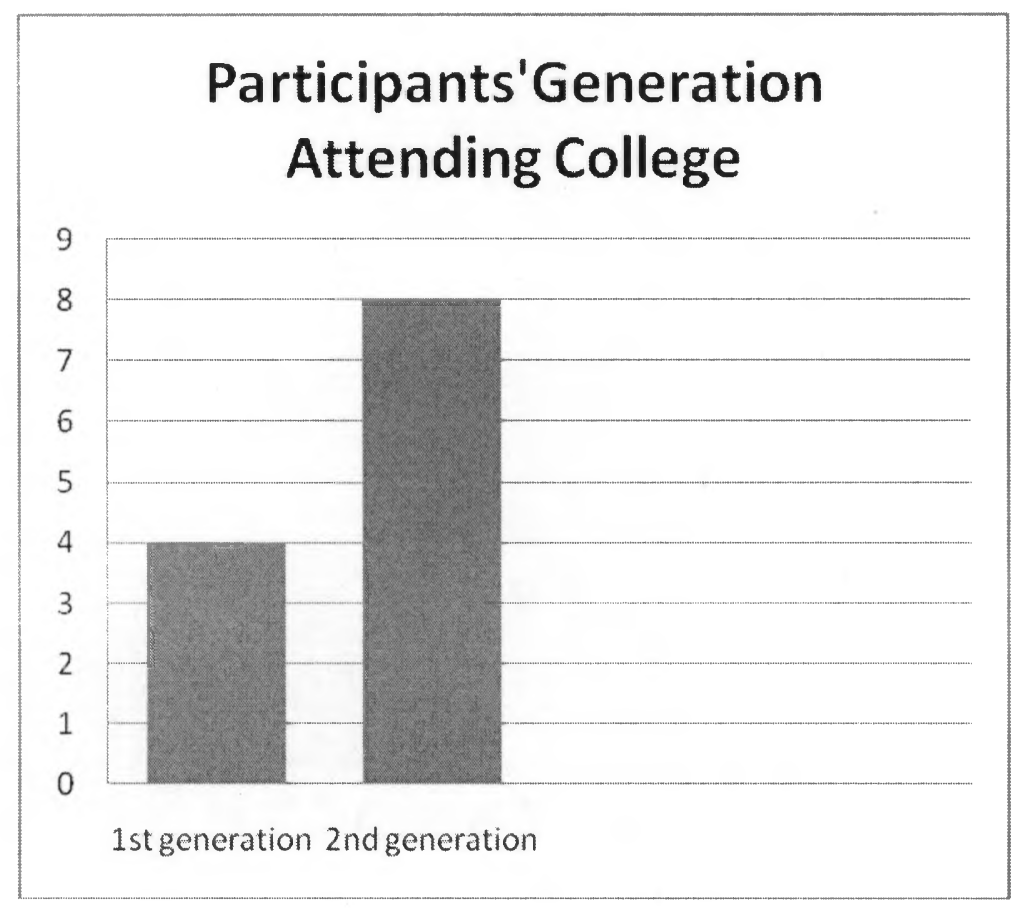

Figure 5. Participants' Generation Attending College

\section{Ethics}

The study was approved by the Human and Animal Subjects

Committee at San Francisco State University and there was no harm done to participants in this study. At the conclusion of the data analysis, I shared my findings with the participants.

A \$20 gift for participation was provided to each participant as a means of compensation for the time he or she spent providing data for the study. In addition to the monetary incentive, I also provided each participant with positive encouragement and SFSU scholarship information. I also offered assistance with graduate school applications and a letter of 
recommendation. During the informed consent process, I provided participants with a summary of the study's purpose.

\section{Data Collection}

The instruments used for the study included an in-depth interview protocol and a prompt to collect narrative data from participants-also referred to as a survival narrative (see Appendix D and Appendix E). A survival narrative is a written letter or list of suggestions to other African American transfer students. The interview questions used for this study were piloted with an African American transfer student from College Two and vetted through the dissertation committee. The interview questions asked participants if they had been treated differently in the community college classroom because they were African American; who helped them achieve their transfer success, how their experiences were unique; and what they struggled with as they prepared to transfer. They were also asked what they would tell an administrator to do to improve the transfer process for African American students, if they were first in their family to attend college, what their major was, how many semesters were remaining at SFSU, if they would apply to graduate school, if they applied for scholarships at SFSU, if they attended the SFSU orientation, which services they utilized at their community college and at SFSU as well as how they were impacted by the 
recent budget cuts at SFSU. (See Table 1 for interview questions and the relationship to research questions.) The written survival narrative and the interview were a unique way to collect data that included students' voices.

To maximize instrument validity, I piloted the interview questions with an African American transfer student from College Two. Piloting the questions provided me with information on which questions were unclear or unnecessary. To enhance validity of qualitative data, I tape-recorded each interview in order to produce verbatim transcriptions. I also shared these verbatim transcripts with interviewees to further enhance validity through the member checking process. In addition, consultation with my dissertation committee including my advisor and expert colleagues further enhanced the validity during data collection, informal note-taking, and memoing. Microsoft Outlook was used to communicate with and track emails from participants. A digital recorder was used to record the interviews.

\section{Data Analysis}

Once the interview data were collected, the interviews were transcribed to produce verbatim transcripts using Microsoft Word. The survival narratives were also translated into verbatim transcripts using Microsoft Word. First, I read each interview and survival letter to get an overall sense of each transcript. Next, I carefully reread each transcript and 
conducted multiple evaluations across both sets of transcripts to produce a subject index using Microsoft Word. Key words and phrases from the interview protocol, responses, and survival narratives were used in initial indexing and coding. These codes were developed and refined in data analysis. Data analysis included cataloguing categories to confirm and expand the theme indices derived from data analysis of the interviews and survival narratives.

Data discovery began with an "intelligent reading" of the transcripts to develop a preliminary understanding of the data by writing short memos consisting of phrases and thoughts in the margins as well as developing of a codebook. The codebook combined selective coding from the literature review with open coding that helped organize the data, as new codes were added or removed during this process. A second reading entailed a line-byline scrutiny that created categories, proposed possible relationships among categories, and uncovered a combination of open and axial coding to develop core categories.

The text was considered in small segments, sentences, phrases, and paragraphs, and a tag was assigned to each segment. Tags were developed inductively from participants' exact words, from survival narrative phrases, and from a review of the literature. The constant comparison approach (Glaser 1965; Patten, 2009) was used throughout to compare new elements 
of data with previously coded data, which refined emerging categories. A matrix with grouped evidence and broader themes was developed.

\section{Transferability of Findings}

Based on the qualitative research design and the predominantly African American, traditional-age, female sample, the findings of the study may be transferable to African American students at other colleges with similar demographics. The findings may also apply to other student populations who have low transfer rates and who experience racism and microaggressions, and who benefit from othermothering such as students who have low income, are the first generation of their family to attend college, and are from non-white racial and ethnic groups. 


\section{CHAPTER 4. FINDINGS}

\section{Overview}

The research questions that guided this study included (a) how does race and racism impact African American transfer students' experiences; (b) what are the major barriers and facilitators to successful transfer; (c) what recommendations do recent African American college transfer students have for other African American students and college personnel. The study explored the proposition that faculty and staff members engage in othermothering as they help African American students navigate the community college.

The findings below are actual African American student counterstories about their experiences preparing to transfer from community college. Counterstories come from the critical race theory tradition. They are a method of telling the stories of disenfranchised people whose experiences are not often told. These counterstories can serve to disrupt complacency, challenge the dominant discourse on race, and advance the struggle for racial reform (Solórzano \& Yosso, 2002). These students' counterstories shed light on the intersection of race and transfer in the community college. To better understand each participant, the following portraits describe each student. 


\section{Student Portraits}

\section{Marquida}

Marquida is a 26-year-old African American woman and is the first person in her family to attend college. She attended College One, College Three, and another community college in the East Bay area. She had two discouraging experiences with two different counselors but also received support from peers and family members, as well as the counseling and transfer centers while attending community college. Her major at San Francisco State University (SFSU) is Communications. She has one more semester before graduation and plans to attend graduate school.

\section{Tenile}

Tenile is a 23-year-old African American woman who attended Riverside Community College, La Sierra College, and College Three. She is also the first person in her family to attend college. While attending College Three. She received support from peers, Extended Opportunity Programs and Services (EOPS), and the Financial Aid and Counseling Offices. Her major at San Francisco State University is Business Finance and she has one semester left before graduation. Tenile is unsure about attending graduate school. 


\section{Jae}

Jae is an African American woman, who is older than traditional college student age; she is the first member of her family to attend college. She attended College Three and received support from family members, peers, instructors, Disabled Student Programs and Services, EOPS, and the Financial Aid and Counseling offices. Her major at SFSU is Communications. Jae has adult children and her grandson also attends SFSU.

\section{Karanna}

Karanna is a 33-year-old African American woman who attended College Three and received support from the EOPS and Financial Aid offices. Like the previous students, she is also the first person in her family to attend college and her major at SFSU is Communications. Karanna is also interested in attending graduate school. She has an adolescent son and receives support from her family while she matriculates at SFSU.

\section{Taneko}

Taneko is a 23-year-old African American woman who attended College Two and was a high-level student leader there. She received support from various staff members, peers, CalWorks, EOPS, and the Financial Aid office. Her major at SFSU is English, she has two semesters before graduation, and she is interested in attending graduate school. 


\section{Genny}

Genny is also an African American woman, aged 22, who attended College Three. She received family support and did not utilize any student services while attending community college. Her major at SFSU is Criminal Justice, she has one semester before graduation, and is interested in attending law school.

\section{Shaheela}

Shaheela is an African American woman, aged 21, who attended College Three. While there, Shaheela received family, EOPS, Transfer Center, and Financial Aid support. She was the first person in her family to attend college. Her SFSU major is Psychology and she has one semester before graduation. She is unsure about attending graduate school.

\section{Amber}

Amber is a 22-year-old African American woman who attended College Three. While there, she received family and EOPS support. She is the first person in her family to attend college. Her major at SFSU is Family and Consumer Sciences and she is not interested in attending graduate school. 


\section{Dana}

Dana is a 25-year-old Black woman who is also the first person in her family to attend college. She attended College One and Three and received support from her family, EOPS, and the Financial Aid office. Her SFSU major is Family and Consumer Science, she has one semester before graduation. She is interested in attending graduate school.

\section{Sienna}

Sienna is a 24-year-old African American woman who is the first person in her family to attend college. She was enrolled at College Three and received support from her church, family, and Veteran Services. Her SFSU major is Sociology, she has one semester before graduation, and she is interested in attending graduate school.

\section{Mitchell}

Mitchell is a 30-year-old Black man who attended College One. While there he received support from family members, EOPS, and the Financial Aid office. His SFSU major is Kinesiology, he has one semester before graduation, and he is interested in attending graduate school. 


\title{
Princesca
}

\author{
Princesca is a 21-year-old woman of African American and \\ Japanese descent. She attended College Three and received support \\ from her family and college counselor. Her major at SFSU is \\ Japanese, she has one semester before graduation, and she may be \\ interested in attending graduate school in Japan. \\ Themes found in these demographics were racial heritage, \\ othermothering support, and transformational resistance. In the following \\ section, I will describe these themes as they were found in interview and \\ survival narrative data and integrate the findings from both sources of data. \\ The interview data are more representative of the participants' experiences \\ while the survival narrative data is prescriptive. The narratives are written \\ from successful transfer students to prospective transfer students with \\ suggestions for successful transfer.
}

\section{Racism and Heritage}

A few key themes emerged from the interview and survival narrative data regarding the impact of racism and race on the participants. This impact was experienced by being the only African American in the classroom, receiving racial microaggressions and participating in African American racial heritage. 
Four participants noticed being the only African American in their classes. The students were aware of the lack of common experience between themselves and other students. The following data show the experiences students had with racial microaggressions.

If I was to make a comment or say how I feel about a certain topic or a discussion itself, it would be two or three others who would feel differently and they would attack me... So I would feel intimidated sometimes because I'm out-numbered and I feel like I'm speaking for hundreds of other people who couldn't be in my seat. (Sienna int. 1/22/10, lines 15-22)

Being the only African American in her class caused her to feel alienated, misunderstood, and unheard. No one else in her class shared her perspective or agreed with her. She also felt the pressure of representing Black people as a result of being the only one.

I was the minority so it was like all eyes were on me and I felt like I had to prove myself to everybody...All the other kids in class are like oh she's not serious...l just wanted to prove them wrong...I never heard it, it was just a vibe I would get when I walked into a classroom. (Princesca int. 1/27/10, lines 68-76) 


\section{Racial Microaggressions}

Eight participants discussed racial microaggressions they experienced while preparing to transfer.

I think that a lot of the time, it's sad that, but it's true that we are stereotyped. I even have friends who sometimes make comments, it's like they don't mean to offend, but sometimes they do....Comments like, you're smart for a Black person (Tenile 1/13/10, lines 187-192; 198)

Here Tenile and Marquida describe microinvalidations they experienced and the feeling that their ability was judged as lacking by others because they are Black.

Participants also encountered condescension from other students when they received too much praise for obtaining a good grade. While no student mentioned the precise reason for the excessive praise, the participants felt their race and ethnicity was the reason they received a proverbial pat on the head. One student felt she was encouraged to attend a less competitive university because she is Black. The same student was told by an upper-level administrator that she was not academically successful because of her background. The student believed the administrator thought that because she was a poor Black single mother, she was performing poorly 
academically, not acknowledging the toll her position as a student government leader took on her academic performance.

Another student discussed her interactions with student services staff. She believed several staff members stereotyped students from different ethnic groups and specifically assumed that African American students would be angry. This resulted in a negative interaction with the student including rudeness and an unnecessary disclosure that she was the person in charge of her area. The staff person was anticipating a problem due to her race. It is possible that the impact of overt racism, racial microaggressions, and being the only African American in class impacted the student's intrinsic motivation and desire to be successful despite those very difficulties. These experiences also impact the need for the students to receive or give othermothering since there is no institutional mechanism in place to help students resolve the experiences they have with racism as they prepare to transfer. Support for the discouragement they experience as a result of racism is not built into the student services structure so in many cases the only place students can get support for the racism they experience at college is with other students, supportive teachers, counselors, and family support. 


\section{African American Heritage}

In addition to being the only African American in class and racial microaggressions, the students expressed a desire to succeed based on his or her heritage. African American heritage was a facilitator for the participants.

...I feel that as a Black man I have a responsibility to do schooling to go out and get what I can get. For our past ancestors to go through everything they went through just to make this possible, I think it would really be a slap in their face for us not to take advantage of these opportunities. (Mitchell int. 1/22/10, lines 60-64)

Mitchell's successful transfer is also linked to his desire to progress as an African American man. He was conscious of the historic oppression of African Americans in the United States and felt the need to advance on their behalf.

The way that I am able to adapt, that comes as part of our heritage is being able to adapt. You know, we had to adapt to being slaves to coming here to learning a new language doing all types of things and that is what makes me unique as a student. Because I know where I came from, and I know where I want to go, so each experience I think about my ancestors and about the legacy I want to leave to my son. I do leave impressions on classes because I do try to leave a piece of 
myself in every class I'm in, and try to make sure you don't talk blindly when you come across the next [African American] person. (Karanna int. 1/14/10, lines 81-86; 192-195)

Karanna also makes a personal connection with the slavery African Americans faced and wants to be successful, not just for her son but to ease the path for other African American students who will follow.

\section{Othermothering Support}

Participants revealed receiving a great amount of support from a variety of sources. Othermothering support encompasses those sources of support specifically, how the ethic of care is transmitted, investment in the academic success of the African American student, and support within the institution. The ethic of care is an ongoing, emotional response to an individual's interaction with students. Students were aware that they needed additional support to manage their transfer preparation and they pursued that support. Seven categories emerged within the othermothering theme: transfer center support, counseling support, financial aid assistance, family support, caring instructors, peer support, and asking for help.

\section{Transfer Center}

Nine of the twelve participants interviewed felt the transfer center significantly assisted them in the transfer process. Students also 
discussed and wrote about the importance of researching transfer requirements, becoming familiar with the transfer campus, and meeting with transfer campus representatives for successful transfer. The survival narratives also highlighted the importance of utilizing the transfer center, meeting with representatives from four-year universities, and visiting the selected campus prior to transfer. In the following survival narrative excerpts, students share advice regarding the transfer center. One student discussed the support she received from the transfer center in this way.

The transfer center...I constantly stayed there. They helped me with my application process. Actually the day I sent my application in [there] was a representative there from SFSU. She helped me send my transcripts in, my application and everything. The transfer center was important; I really, really think it is important for people to go here. (Marquida Int. 1/13/10 lines 76-81)

In her survival narrative, Marquida also mentioned the importance of using the transfer center.

Utilize the transfer center and all of its resources. They have people there who are willing to help you step by step in your transfer process. They also have great tips in helping you transfer over. I would say make the people in your transfer center your best friend. They will be 
like a go-to support house for all your questions \& concerns.

(Marquida survival narrative, 1/13/10, lines 9-12)

The participants directed other students to use the transfer center. It was an integral part of their transfer process. In addition to the center, some participants felt it was important to do independent research on transfer requirements and investigate the transfer campus.

Know what classes are needed to transfer; take classes that will transfer over at a four-year school; connect with someone at the fouryear institution they want to attend. (Mitchell survival narrative, 1/27/10, lines 135-137)

The transfer center was a key area of support for the participants. Many students received help from staff, did independent research on transfer requirements, met with representatives from four-year universities, completed their CSU application, arranged to have their transcripts sent to SFSU, and researched four-year institutions of interest. The transfer center was a place where students developed rapport with other staff and students. They ultimately felt comfortable asking for help and were satisfied with the support they received. 


\section{Counseling Support}

Another key facilitator for the participants was counseling support.

Counseling in a California community college is typically personal, academic, or career advising. Counselors assist students with selecting courses, determining goals, making educational plans of required coursework spanning several terms, and overall navigation of the college. Nine out of twelve participants discussed the importance of counseling and ten out of twelve survival narratives urged students to utilize counseling services. ...A lot of African American students don't know who their counselor is, they make class schedules on their own. They might see them once or twice and get a printout of the classes they should take and go off on their own. But you really need a body to talk to, you need to look at somebody and have them sit you down with your papers, your goals and just work with you. Counselors are amazing people because they can tell you what you need and what you don't need just straight off without looking at their computer and that's what they're there for. So counselors are great gifts to colleges. (Sienna int. 1/22/10, lines 290-298)

Sienna was reflecting on what helps African American students persist and transfer from community college. Other participants also shared appreciation for their counselors. 
Jamie, she helped me a lot. She always let me know that she was there and gave me her personal card, and if I ever needed to call her I could do that. I feel like I could just always run to Jamie if I needed anything. And I don't even think she knows that she helped me a lot but she definitely did. (Princesca int. 1/27/10, lines 125-129) A few students had negative encounters with counselors. Three participants revealed their experiences with counselors.

She kind of... told me, not with the same words that I'm basically not going to make it and that... killed my drive. (Marquida int. 1/13/10, lines 48-50)

Marquida described being told by a counselor at College One that she wouldn't successfully transfer or pass her math class. As a result of hearing those negative messages, Marquida decided to attend College Three, which was more supportive for her. However, Marquida's negative experiences with counselors did not end at College One. She also saw a counselor at a community college near Alameda where she experienced a racial and gender microaggression during her counseling appointment. As she explained, A lot of people that I meet didn't think I had the good grades I had. I went to one counselor in Alameda, because I needed to take a class over there, and I met with him. And he was surprised when he pulled 
up my transcripts from Contra Costa and this district, and he seen all the B's and the As, and he was like, I wouldn't have thought that you were that smart. He was like, not a bad thing, it's just that when you walk in you give off the persona like you're bubbly and you're airheaded, he said. And so it was interesting to see that you were so smart. And it kind of threw me away, threw me back, and like whoa, so I think my experience is unique just for the simple fact people underestimate me and they don't think that I'm capable of doing the things that I am doing like, I finished off my first semester at SFSU with three B's and a C. (Marquida int., 1/13/10, lines 138-149) Participants' survival narratives noted the importance of meeting with the same counselor regularly, developing an educational plan with the counselor, and checking it often to make sure they stayed on track with transfer requirements. Students who had negative experiences also discussed the positive experiences they had, and they attributed some of their success to the personalized guidance they received.

\section{Family Support}

Ten participants discussed the family support they received and two discussed their lack of family support. Nine students were the first in their families to attend college, so while the majority of participants did not have a 
parent who had attended college, they were still able to draw considerable support from family members. Mitchell mentioned his sister and godmother who supported him.

My sister...she would just talk to me on a regular basis. Sometimes when I would get frustrated with how things were going, whether it was because I had to miss a semester or because I had to work, she encouraged me to get back in there. And pretty much my godmother was the same... just stay with it and see it through. (Mitchell int. 1/27/10, lines 73-77)

Two students had no family support. One mentioned she received much of her support from staff on campus instead of family members.

Most of the students discussed the benefits of receiving family support during the interviews. They received financial assistance and ongoing verbal encouragement of their ability to transfer and graduate. Family members who gave this support were parents, grandparents, godparents, siblings, cousins, adult and young adult children, co-parents of students' children, and spouses.

\section{Caring Teachers}

Four student interviews and five survival narratives discussed the care and support they received from their teachers. Some students mentioned 
feeling as if their instructors truly cared about them; others were directly encouraged by instructors and consequently felt they could be successful. I've had a lot of teachers that have just encouraged you to do better, you know what I mean, and just make you feel like you can do it, you know? By just encouraging you to do your best, you know. And just, they just feel just really supportive you know. You can tell they want you to do better. (Tenile int. 1/13/10, lines 321-328)

You know, it's funny because my teachers became not only my teachers but my friends, you know. So that made it a lot easier for me to learn, when I didn't understand something I would come in early, or I would stay late, or I wasn't afraid to ask. (Jae int. 1/13/10, lines 5054)

Both students expressed receiving care and commitment to their educational goals from instructors, which is reminiscent of the ethic of caring in othermothering. Because that support was above and beyond typical faculty duties in a community college, it conveyed a sense of investment in the students' educational future, and because it was given to African American students, it could also be considered othermothering. 


\section{Student Peer Support}

Only three students discussed support from other students but five narratives mentioned the importance of student peer support.

I do feel like, like friends are really helpful, and I asked a lot of questions from people who went there or were planning on transferring, and so a lot of my info came from other students. (Tenile int. 1/13/10, lines 139-142)

Students benefitted from interacting with other students who were also planning to transfer. It helped them to discuss transferring often with other students, and transfer center student workers. They also seemed to benefit from study groups with students and mentoring from those who had recently transferred.

\section{Othermothering}

Othermothering and asking for help were also discussed by half of the participants. Embedded within othermothering was an investment in the student's academic success as an uplifting action for African Americans. Othermothering was found in a variety of ways. Some students received it from student peers, family, counselors, and teachers while others gave it to other students, youth in the community, and me. The participants all responded within $24-48$ hours to my initial email because they wanted to 
support a fellow African American student working to achieve a doctoral degree and their fellow African American transfer students.

I work at the flea market, and every young person that I see, the first thing I ask is are you in school, and I preach, you know, and tell them... I tried to instill in my kids, in my grandkids how important it is, but not only my grandkids, but any kid that I see, you know. (Jae int., 1/13/10, lines 288-292)

Jae not only encouraged her children and grandchildren to attend college but any young person of any ethnicity that she met outside of college.

"Don't ever be ashamed, scared to ask for assist in any area" (Sienna, survival narrative, 1/22/10, line 123).

Students participated in othermothering by making sure they supported other African American transfer students with their study participation, encouraged other young people to go to college, and worked hard academically to leave a legacy of higher education for their children. Some students also discussed receiving othermothering from college staff people.

\section{Resilient Resistance}

Resilient resistance was the third theme found in the study and includes intrinsic motivation and the desire to "prove them wrong" (Yosso, 
2000). Resilient resistance occurred as African American participants made clear and conscious decisions to successfully transfer from the community college. Transfer success was their way to resist the racial microaggressions and underestimations of cognitive ability they experienced in the classroom. The students expressed a clear desire to succeed regardless of the difficulties they experienced. They expressed an intrinsic motivation and attributed it as a key element to their success. Participants also expressed a desire to prove people who underestimated their academic ability wrong.

\section{Intrinsic Motivation}

Ten participants discussed an innate desire to further their education. The students were internally motivated to transfer and academically succeed. The excerpts below demonstrate the intrinsic motivation and value they placed on higher education.

I wanted more for myself, I wanted to better myself and I wanted to learn more. And so, I basically just, I couldn't stop, I can't stop. I think I'm successful. (Marquida int.1/13/10, lines 106-108) ...I feel like in my life I've had so many examples of what I don't want, you know you kind of figure out what you want and you go for it, you know? (Tenile int. 1/13/10, lines 158-161) 
The students were very determined to succeed academically. While they acknowledge the encouragement they received from others, their internal drive was the key to their ability to persist in community college and transfer. They described their own desire to be educated, learn more, be positive, and persevere and the importance of pursuing higher education. The students also connected the significance of knowing what one wants in life to their ability to remain enrolled. Participants described a sense of personal accountability for achieving their academic goals. In the survival narratives, students wrote about the importance of transferring to a four-year college or university and the ability to obtain a better job as a result of obtaining a Bachelor's degree.

\section{Proving Them Wrong}

Five participants discussed being successful in the classroom despite others' low estimation of their cognitive abilities. Proving them wrong was an aspect of their resilient resistance and racial experiences in transfer. Proving them wrong speaks to the desire the students expressed to succeed despite the negative expectations others had for them in the classroom. The following quotations demonstrate this phenomenon.

Out here [College One] I don't come across too many Black faces...I wanted to excel because I didn't want any special favors, like 
ok he's one of the only Black students in here so maybe he's not able to keep up with the rest of the students or anything like that, so I didn't want any special favors in that regard... It made me want to try harder. (Mitchell int. 1/22/10, lines 46-60)

I could have listened to her, that one counselor, and dropped out of school and said forget it I'm not going to make it. But instead I turned it around and I actually transferred despite what she said and despite that she said I was never going to make it out [of] the math class, I couldn't do this--'I couldn't' is not in my vocabulary. I can do it, and I am doing it. (Marquida int. 1/13/10, lines 113-118)

Mitchell wanted to succeed because he is an African American man and he wanted to change the perception that African Americans are not intellectually competent. Marquida had a profoundly negative experience with a counselor who outwardly doubted her ability to succeed; that negative experience spurred her on to successfully transfer.

\section{Student Recommendations}

The students also discussed recommendations for changes that faculty and staff can make to improve the transfer experience for other African American students. They made suggestions for college employees and prospective transfer students. The students shared very specific 
suggestions for improving the transfer process for African American students at the community college. The majority of these recommendations came from the survival narratives.

Um, that one counselor that told me I would not make it, I would actually sit her down and let her know that what she did was not ok. She ...killed my spirit, and she almost stopped me from wanting to achieve my goals... instead of like talking down upon people and looking down upon people, she should lift them up. She was kind of rude, and just let her know that if you be a little personable, just uplift the students, then it would help the process 'cuz by me being African American, a woman, I have two things against me. I don't need for her to tell me what I'm not going to be able to do. Make that personal connection, get with a counselor you feel comfortable with and stick with that counselor. (Marquida int. 1/13/10, lines 270-281)

Marquida was able to critique her experience with the counselor, suggest ways to improve the experience for future students and encourage students to see the same counselor. She was able go beyond her negative experience and direct students to the service as it fits them.

I'd probably tell them, to have a class with African American students that are transferring...[like] orientation. It would probably inspire a lot of the students like oh she's doing it too, I'm not the only one here and 
then they'll get to make friends and maybe pick classes together so that it'll be easier for them and make them want to go to school... (Princesca int. 1/27/10, lines 156-163)

Princesca articulately recommended a course for African American transfer students so they can become familiar with each and support each other as they prepare to transfer. This camaraderie would lessen the alienation the participants expressed as the only African American in their class.

By just encouraging them, and saying hey, have you thought about going here, or...letting them know how much, having a four-year degree can change your life, you know what I mean? Just letting them know they can do it, you know? (Tenile int. 1/13/10, lines 419-423) The participants recommended several things to improve the transfer process for other African American community college students. They suggested the college make financial aid, counseling, and transfer center information more available to students through class visits. One student recommended that counselors refrain from telling students they won't be successful but positively encourage them, have a caring attitude, and uplift students instead. Counselors also need to let students know that a degree is not required for transfer. Specific recommendations included allowing counselors to spend more than 20 minutes with students, providing appointments for continuing students between semesters, and giving 
students instructor recommendations. Students want more resources as well as genuine, concentrated assistance form counselors. One student recommended that a counselor be designated for transfer so he or she can be more familiar with the students and exclusively focused on those requirements, and a class to ease the transition of transfer students. Students felt counselors should create educational plans with math and English requirements completed in their early semesters. Others felt all undecided students should take a career planning course to assist them in developing a goal. Another student suggested a course for all African American students so they can get to know each other, plan classes together, and lessen the isolation experienced by being the only African American in the classroom. They suggested that front-counter student services staff not stereotype people but treat students at the window more positively. Another recommended students become active in academically oriented organizations that would challenge them and set a higher level of expectation.

In addition to the interviews, data were collected regarding recommendations in the survival narratives.

...Be determined to pass all courses with a $C$ grade or higher; get to know professors-you may need them in the future — this also guarantees success in that course; do not rush or carry a hectic 
schedule, only what you can manage; be patient for state [SFSU]

frustration will only slow you down, every student has their own educational path, never compare yourself to others. (Sienna survival narrative, 1/22/10, lines 111-125)

Students expressed strong sentiments of encouragement and motivation in their survival narratives to other African American transfer students. They recommended students not compare themselves to others or be discouraged by setbacks and suggested they learn from their mistakes. Taking the assessment test, getting involved in student clubs, connecting with instructors, using the library, and being selfish about their educational goals were some of their suggestions. Other suggestions were to not procrastinate, be determined, get advice from teachers, enjoy themselves, attend school full time, take summer classes, get $\mathrm{C}$ grades or higher, and avoid a rushed hectic schedule. Students also felt that prospective transfer students should surround themselves with positive people and develop friendships with other transfer students and be patient. The students gave concrete advice based on their own experiences. This advice might also meet the criteria for othermothering as the students are consciously recommending things that mitigate some of the challenges they faced. 


\section{Relationships}

Many of the areas above could be cross-listed. Proving them wrong was both a facilitator and a barrier. Because there were some odds associated with being African American, this phenomenon could be viewed as a barrier. However, the students were motivated to succeed as a result of these odds so it facilitated their ability to transfer.

\section{Summary}

Othermothering support, transformational resistance, and racial heritage were key barriers and facilitators for transfer. African American students significantly benefitted from the extra support and investment in their success that came from family members, instructors, and other students. While racism was a part of the students' experiences, an aspect of this racism, the racial microaggressions, and a connection to the historic oppression of African Americans spurred the students on to academically succeed.

The following chapter further analyzes the findings from this study and lists recommendations towards the goal of improving the transfer experience for African American community college students. Main conclusions based on these findings are also presented. 


\section{CHAPTER 5. CONCLUSIONS AND RECOMMENDATIONS}

\section{Overview}

When I began this study, I wanted to explore the experiences of African American community college transfer students in order to improve the transfer process. The goals and objectives of the study were (a) to document and understand the impact of racial microaggressions from the perspective of African American students who had recently transferred; (b) to gain a greater understanding of how interpersonal relationships affect successful transfer; and (c) to explore the facilitators and barriers to transfer for African American students. Another purpose of the study was to capture the perspectives and experiences of African American students in their own voices. The study's qualitative methodology and critical race theory framework emphasized student voice through in-depth interviewing and counter-narrative analysis. Study participants wrote about and discussed the challenges and support they received while preparing to transfer from Northern California community colleges.

The research questions explored for the study were the following: (a) How do race and racism impact their experiences? (b) What are the major barriers and facilitators to their successful transfer? (c) How do African 
American students experience the transfer process in the East Bay Community College District?

The study found that African American community college students experience unique challenges and support structures in higher education settings, in general, and the transfer process, in particular. The findings of this study further indicate that othermothering as well as transformational resistance may serve to ameliorate the negative experiences and structural barriers that usually thwart the transfer aspirations of African American community college students. Findings from this study also confirm that African American transfer students continue to suffer from racism in the form of racial microaggressions while attending community colleges. Lastly, while othermothering originates from African Americans, "othermothers" can be men and women from other ethnic groups.

In spite of these unique experiences, African American students also struggle with challenges that many students appear to face regardless of ethnicity. All students in the study discussed the need for financial aid, supportive instructors, and understanding and completing transfer requirements much like other community college students l've worked with who were not African American. However, the student participants were also aware of negative societal and institutional perceptions of African Americans. During their community college attendance, they experienced racial 
microaggressions, engaged in transformational resistance, and benefitted from othermothering support.

The major findings from this study relate to the following topics in the research literature: (a) the documentation of continued racial microaggression as experienced by African American community college students; (b) the unique role of othermothering in facilitating transfer; and (c) the role of resistance in persevering in community college and the transfer process. Students were aware that they struggled with racial microaggression and needed support beyond basic counseling or instruction. The care, cultural advancement, and guidance they received from othermothering helped them navigate from community college to the fouryear institution. Furthermore, racism and racial microaggression continue to hamper and harm African Americans in community colleges. In response to these racialized experiences, some African American students consciously or unconsciously engage in different forms of resistance (as discussed in Chapter Two) that help them to negotiate and navigate the educational pipeline.

Research studies have often focused on African American community college students but they have not addressed transfer success from the student perspective. Using a qualitative critical race methodology case study design, this study focused on 12 African American students currently enrolled 
at San Francisco State University who had attended community colleges in the San Francisco Bay area. Through interviews and written survival narratives that recommended what other students should do to transfer, I learned about the nature of their experiences and the sources of support and discouragement as well as the impact of race and racism on their experiences. In addition, I learned about what the students felt community colleges could do to improve the transfer process for other African American students.

The findings confirm previous studies that found that African American community college transfer students need targeted support from counselors, faculty, and peers in order to persist and transfer to four-year institutions (Glenn, 2004; Greene et al., 2008; Haro 2004; Volkwein et al., 1986).

Research literature maintains that this group of community college students also struggles with additional cultural and racial barriers (Derby \& Watson, 2006; Museus et al., 2008). According to these researchers, African American community college students need support from counselors, family members, faculty, staff, and other students to combat the racism they experience and to succeed in transferring to four-year institutions.

\section{Racial Microaggression}

With the election of U.S. President Barack Obama, many have tried to 
argue that we live in a post-racial era (Souleymane, Bachir \& Diagne, 2010; Sparks, 2009); however, findings from this study document that African Americans continue to experience racism in higher education settings. The students had experiential wisdom regarding the intersection of their race/ethnicity and their educational pursuits. They understood that societal bias against Black people affected them at the community college and that they would have barriers to transfer, specifically, experiences with racial microaggressions from classmates and counselors as well as isolation from being the only African American in the classroom. They were aware that their success would be an exception to the dominant story told about African Americans in higher education. Yet the students were committed to their own narrative: successful transfer to and graduation from a four-year university. The participants had a keen understanding of the impact of racism on their educational journey. The participants experienced racial microaggressions from other students and counselors. The racial microaggressions occurred when evidence of their good grades became apparent and when students openly expressed that the capable African American students in their midst were "smart for their group." This is a common racial microaggression that assumes that African Americans, as a group, are not smart. In this case the assumption was made in class by other students and in the counseling office by a counselor. 


\section{The Role of Othermothering}

This study found that othermothering can play a profound role in the success of African American community college transfer students.

Othermothering connects African American students and teachers and is characterized by an ethic of care, cultural advancement and institutional guardianship. Educators typically help African American students combat racism and develop socially, psychologically and academically. Similar to othermothering in the African American community is "cariño," or "authentic caring," in the Latino community. This construct shows a deeper sense of caring to Latino students (Valenzuela 1999).

For these participants, othermothering manifested as assistance that was above and beyond typical helpfulness, demonstrated a deeper level of care, and an investment in their success. This deeper level usually involved some sacrifice on the part of the othermother. The students were aware of that sacrifice and understood the support was authentic as a result of that sacrifice. For example, one student felt her counselor leveled with her by discussing her strengths and weaknesses as they related to her major, then

guided her to a major that would accentuate her strengths and enable her to transfer earlier. Such a conversation can be risky and involves a deeper commitment to the student's success. In this case the counselor ran the risk of not being "liked" by the student to enhance the student's success. Study 
participants acknowledged the complexity of othermothering and appreciated the risk and investment in their success. This risk may also be considered like a sacrifice, one that made the othermothering feel like authentic care. Key othermothering sources included transfer center staff, counselors, faculty, and students. Students who discussed using the transfer center were able to develop rapport with staff and students and ultimately felt comfortable asking for help and were satisfied with the support they received.

Another source for othermothering was counseling support.

Participants noted the importance of developing rapport with the same counselor. They felt they benefitted from personalized advising. Some participants felt they successfully transferred as a direct result of the counseling othermothering support they received. The students received othermothering from instructors during the interviews as well. One quarter of the students mentioned feeling as if their instructors truly cared about them, were directly encouraged, and consequently felt they could be successful. Because the support was above and beyond typical faculty duties and conveyed a sense of investment in the students' educational future, it is considered othermothering. Students also received othermothering support from other African American students who had recently transferred before them and from college staff, counselors, and family members. In addition, 
some students performed othermothering on local community youth and fellow students.

Because the students were aware of the negative biases against them as African Americans in higher education, the above and beyond support of othermothering, was an important aspect of transfer. The relationships they had with faculty who encouraged them inside and outside the classroom; with counselors who became familiar with them, made instructor and course recommendations, were available for questions; with supportive family members and staff in administration, student services, and writing centers who encouraged the students all served to assist them in the transfer process. Students in the study received othermothering from men and women of a variety of ethnicities. Some but not all of the "othermothers" were Black.

\section{Transformational Resistance}

The students were also proud of their race/ethnicity and conscious of the trials and tribulations experienced by past generations of African Americans. This connection to their ethnic group combined with a sense of determination to succeed academically for themselves, their families, and their ancestors. As the students understood their struggle with racism, they also knew they needed additional support, othermothering, to deal with the 
racism and persist through the college. Another way they resisted that racism was through transformational resistance, their determination to academically succeed.

The students in this study employed transformational resistance and sought additional assistance and encouragement, in the form of othermothering, to successfully navigate the transfer process. The wisdom these students possessed and experiences they had as Black people incited them to participate in higher education to the best of their ability, engaging in transformational resistance.

\section{Limitations}

Limitations for this study include the small number of participants (12) who were interviewed. Furthermore, in order to fully understand the true barriers to transfer, it would be necessary to include students who were eligible to transfer but who did not. In addition, the gender of the participants was not balanced. Eleven participants were female and one was male; this might also affect the recognition of othermothering among the participants. While the small convenience sample included in this study may limit external validity in a positivistic framework, I believe my qualitative findings are transferable to other African American students in higher education settings with similar demographics. 


\section{Implications for Improving Practice}

Findings from this dissertation study demonstrate the urgent need to improve campus climate regarding race and racism. Improvements in counseling, staff, faculty, administrative, and student practices as well as family support can better serve African American community college transfer students. However, these improvements must be driven by administrators and implemented by staff and faculty members on the ground level of the institution.

\section{Recommendations}

Administrator recommendations. Administrators need to invest and commit to actively combating barriers for African American students. They can do this by supporting the development of faculty and staff training and practices that address racial microaggression, othermothering, and transformational resistance. They should regularly hold roundtable discussions with counselors and students geared toward improving the counseling experience for students and enhancing counselor encouragement. These roundtables could occur free of charge during the faculty development week (Flex week) that precedes fall and spring semesters. According to the students in this study, administrators need to increase the time counselors have with students, refocus the transfer center 
and counseling services to operationalize othermothering and increase outreach to students. Administrators also must ensure that student service offices treat students positively and provide bias and racial microaggression awareness training to employees. Implementation of critical race pedagogy and enhancing ethnic studies offerings could enhance transformational resistance; therefore, administrators could work with faculty to include these course offerings as well. Lastly, administrators should provide staff, faculty, and management with the necessary tools and training to handle complaints involving racism, racial microaggressions, and other forms of oppression. Campus equity committees could be charged by administrators to develop and implement these trainings to work toward greater equity on campus. 
Counselor recommendations. Counselor encouragement made all the difference to the students in the study. Counselors should operationalize othermothering by becoming familiar with students' goals, likes, dislikes, and learning styles; sharing their institutional knowledge on courses and instructors with students; creating student educational plans with math and English requirements completed early in attendance; and being personable, uplifting, and positive with students. Counselor discouragement was also a barrier for African American students. Lastly, counselors should develop a procedure for dealing with complaints regarding racism and other forms of oppression that provides constructive criticism and feedback for improvement to the counselor.

Faculty and staff recommendations. Faculty members also play a critical role in supporting African American transfer students. Critical race pedagogy and ethnic studies are key vehicles for enhancing transformational resistance among students. Faculty members should also be personable, positive, and uplifting when interacting with African American students and share their area of expertise with students. Faculty members must manage the racism that occurs in their classes, and staff and managers must handle the racism that occurs in their offices. Study participants felt faculty should be available to get to know African American students

I also encourage the addition of racial microaggression awareness to 
faculty, staff, and manager evaluations. Including more specific questions about racism may yield more data on students' experiences with racism. The existence of evaluation questions, course content, and staff development activities regarding racial microaggressions may serve to affirm the experiences of African American students and demonstrate institutional recognition that racism exists on campus.

Student recommendations. In addition to the othermothering, documentation of racial microaggression and transformational resistance, there were student recommendations for enhancing the transfer experience. Students provided deliberate participation in the study to help future transfer students. They shared several recommendations for African American students currently in the transfer pipeline.

As previously mentioned, the students felt prospective transfer students should meet with the same counselor on a regular basis, have an educational plan developed, and complete all transfer requirements. They included encouraging, realistic, and positive feedback geared toward academic success. They encouraged other students to apply for financial aid, utilize the transfer center, take a career planning course if undecided, ask for help, surround themselves with positive people and students with similar goals, get to know their instructors, avoid procrastination, pass all courses, attend full time whenever possible, and be patient with themselves 
throughout the process of transferring. They also encouraged students to plan to take classes together to reduce isolation in the classroom.

SFSU recommendations. SFSU should increase communication with community colleges to improve social and academic integration. Participants shared that they felt very supported at the community college and much less supported at SFSU. For that reason, l'd suggest SFSU implement othermothering in advising and student support offices. Students also experienced difficulty connecting with other African American students at SFSU. To reduce this barrier, I would urge SFSU to develop an orientation for African American transfer students to formally create an opportunity for social networking and isolation reduction as well as creating less formal opportunities for social networking among African American transfer students.

For this study, I found 12 African American San Francisco State University students who successfully transferred from Bay Area community colleges. They all experienced challenges and supports as they prepared to transfer. I found that these students struggled with racial microaggressions from other students and counselors and lack of encouragement from counselors. Othermothering from counselors, transfer center staff, faculty, peers, family, financial aid, contributing to an African American legacy of higher education, and transformational resistance facilitated their transfer to 
SFSU. African American community college students benefit from the same othermothering earlier generations of African American experienced in Southern segregated schools. And African American community college students benefit from othermothering done by a variety of people from both genders and diverse ethnic groups.

\section{Implications for Further Research}

Educational research can help fill the gap in African American community college student-voiced research. There is very little studentvoiced research on African American community college studies.

While this study focused on African American community college students who transferred to a four-year institution, studying students who did not transfer would provide additional data on barriers to transfer. This study also provided additional information on the role of othermothering in academic success for African American community college students. Further research is needed on othermothering and community college students. In this study, African American students benefitted from the othermothering they received from staff and faculty who were not African American; further research is needed on the intra-ethnic application of othermothering. There is also a lack of research on critical race theory in community college settings. Further research is needed on the application of CRT to community colleges 
and specifically the role of the administration in eliminating barriers for African American community college students.

Opportunities for a greater standard of living are reduced without higher education, so for African Americans who do not transfer and graduate from four-year institutions these opportunities are out of reach. What can community colleges do to improve transfer preparation for African American students? What kinds of relationships and support foster successful transfer for African American community college students?

According to this study, community colleges have the tools necessary to create bias reduction trainings, demonstrate care, and improve transfer rates for African American students. There a plethora of committees including an equity committee charged with reporting and encouraging the progress of underrepresented students, and best practices in instruction, counseling, and student support. All of these things combined with ongoing training can enable community colleges to improve transfer preparation, foster successful transfer, and reduce racial microaggressions for African American students. 


\section{REFERENCES}

Banks, J.A. (1993). The cannon debate, knowledge construction and multicultural education. Educational Researcher. 22(5), 4-14.

Bell, 1992 (1993). Faces at the bottom of the well: The permanence of racism. Harvard Law Review, 106(6), 1358.

Bensimon, E., Hao, L., \& Bustillos, L. (2003). The state of equity in California's postsecondary education system. Paper presented at the Harvard Civil Rights and UC Conference on Expanding Opportunity in Higher Education: California and the Nation.

Bryant, M. (2006). Talking about change: Understanding employee responses through qualitative research. Management Decision, 44(2), 246-258

California Community College Chancellors Office. (2008). California Community Colleges System Office. Retrieved from http://www.cccco.edu/ChancellorsOffice/tabid/179/Default.aspx

California Community Colleges System Office. 2010. Focus on results: Accountability reporting for the community colleges.

California Postsecondary Education Commission. (2010). Custom Report. Retrieved from 
http://www.cccco.edu/ChancellorsOffice/Divisions/TechResearchlnfo/ MIS/DataMartandReports/tabid/282/Default.aspx

Carnoy, M., \& Levin, H. (1985). Schooling in the democratic state. Palo Alto, CA: Stanford University Press.

Case, K. I. (1997). African American othermothering in the urban elementary school. The Urban Review, 29, 25-39.

Chang, J. C. (2005). Faculty-student interaction at a community college: A focus on students of color. Research in Higher Education, 46(6), 769802.

Collins, K., Onwuegbuzie, A., \& Jiao, Q. (2007). A Mixed Methods Investigation of Mixed Methods Sampling Designs in Social and Health Science Research. Journal of Mixed Methods Research, 1(3), 267-294.

Collins, P. H. (1991). Black feminist thought: Knowledge, consciousness and the politics of empowerment. New York: Routledge.

Collins, P. H. (2000). Black feminist thought ( $2^{\text {nd }}$ ed.). New York: Routledge. Community College League of California. (2010). Fast Facts 2010. Retrieved from www.ccleague.org

Contreras, A.R. (2004). Epilogue: Latinos at the Portal of the $21^{\text {st }}$ Century. Education and Urban Society, 36, (223-234). 
Crenshaw, K, Gotanda, N., Peller, G., \& Thomas, K. (Eds.). (1995). Critical race theory: the key writings that formed the movement. New York: New Press.

Creswell, J. W. (2005). Educational research: Planning, conducting and evaluating quantitative and qualitative research ( $2^{\text {nd }}$ ed.). Upper Saddle River: Pearson Education.

Cruz-Janzen, M. (2002). Lives on the crossfire: The struggle of multiethnic and multiracial Latinos for identity in a dichotomous and racialized world. Race, Gender and Class, 9(2), 47-57.

Delgado, R., \& Stefancic, J. (2001). Critical race theory: An introduction. New York: New York University Press.

Derby, D. C., \& Watson, L. W. (2006). African American retention within a community college: Differences in orientation course enrollment. Journal of College Student Retention, 8(3), 377-390.

Dougherty, K. (1992). Community colleges and baccalaureate attainment. Journal of Higher Education, 63(2), 188-214.

Dougherty, K., \& Reid, M. (2007). Fifty states of achieving the dream: State policies to enhance access to and success in community colleges across the United States. Online Submission. http://www.eric.ed.gov/PDFS/ED500216.pdf 
Duncan-Andrade, J. (2009). Note to educators: Hope required when growing roses in concrete. Harvard Educational Review, 79(2), 181-194.

Elliott, J. (2005). Using narrative in social research: Qualitative and quantitative approaches. Thousand Oaks, CA: Sage.

Feist-Price, S. (2001). African American faculty mentoring relationships at predominantly White institutions. Rehabilitation Education, 15, 47-53.

Foster, M. (1993). Othermothers: Exploring the educational philosophy of Black American women teachers. In M. Arnot \& K. Weiler (Eds.), Feminism and social justice in education: International Perspectives (pp.101-123). Washington, DC: Falmer Press.

Gandara, P., \& Educational Testing Service. (2005). Fragile futures: Risk and vulnerability among Latino high achievers. Policy Information Report. Retrieved from www.ets.org.

Glaser, B. (1965). The constant comparative method of qualitative analysis. Social Problems, 12(4), 436-445.

Glenn, F. (2004). The retention of Black male students in Texas public community colleges. Journal of College Student Retention, 5(2), 115133.

Greene, T., Marti, C., \& McClenney, K. (2008). The effort--outcome gap: Differences for African American and Hispanic community college 
students in student engagement and academic achievement. Journal of Higher Education, 79(5), 513-539.

Guffrida, D. (2005). Othermothering as a framework for understanding African American students' definitions of student-centered faculty. The Journal of Higher Education, 76(6), 701-723.

Haro, R. (2004). Programs and strategies to increase Latino students' educational attainment. Education and Urban Society, 36, 205-222.

Hirt, J. B., Amelink, C. T., McFeeters, B. B., \& Strayhorn, T. L. (2008). A system of othermothering: Student affairs administrators' perceptions of relationships with students at historically Black colleges. NASPA Journal, 45(2), 210-236.

Hughes, B. (in press). Learning from history and success: Complementarity between the transfer goals of community colleges and the work of historically black colleges and universities. Community College Journal of Research and Practice.

Iverson, S. V. (2007). Camouflaging power and privilege: A critical race analysis of university diversity practices. Educational Administration Quarterly, 43, 586-611.

Jain, D. (2010). Critical race theory and community colleges: Through the eyes of women student leaders of color. Community College Journal of Research and Practice, 34, 78-91. 
Johnson, R. C., \& Viadero, D. (2000). Unmet promise: Raising minority achievement. Education Week. Retrieved from http://www.edweek.org/sreports/gap.htm

Laanan, F. S. (2004). Studying transfer students: Part I: Instrument design and implications. Community College Journal of Research and Practice, 28, 331-351.

Laanan, F. S. (2007). Studying transfer students. Part II: Dimensions of transfer students' adjustment. Community College Journal of Research and Practice, 31, 37-59.

Ladson-Billings, G. (1998) Just what is critical race theory and what's it doing in a nice field like education? Qualitative Studies in Education, 11(1), 7-24.

Ladson-Billings, G. (2000). Racialized discourses and ethnic epistemologies. In N. Denzin \& Y. Lincoln (Eds.), Handbook of qualitative research $\left(2^{\text {nd }}\right.$ ed., pp. 257-277). Thousand Oaks, CA: Sage.

Ladson-Billings, G., \& Tate, W. F. (1995). Toward a critical race theory of education. Teachers College Record, 97, 47-68.

Loder, T. L. (2005). African American women principals' reflections on social change, community othermothering, and Chicago public school reform. Urban Education, 40(3), 298-320. 
Lorde, A. (1992). Age, race, class and sex: Women redefining difference. In M. Anderson \& P. Hill Collins (Eds.), Race, class and gender: An anthology (pp. 495-502). Belmont, CA: Wadsworth.

McGrath, D., \& Tobia, S. (2008). Organizational culture as a hidden resource. New Directions for Community Colleges, 144, 41-53.

Museus, S. D., Nichols, A.H., \& Lambert, A.D. (2008). Racial differences in the effects of campus racial climate on degree completion: A structural equation model. The Review of Higher Education, 32(1), 107-134.

Patten, M. L. (2009). Understanding research methods: An overview of the essentials. Glendale, CA: Pyrczak.

Petrovitch, J., \& Wells, A. S. (2005). Bringing equity back. New York: Teachers College Press.

Pierce, C. (1970). Offensive mechanisms. In F. Barbour (Ed.), The Black seventies (pp. 265-282). Boston: Porter Sargent.

Provasnik, S., \& Planty, M. (2008). Community colleges: Special supplement to the condition of education 2008 (NCES 2008-033). Washington, DC: National Center for Education Statistics, Institute of Education Sciences, U.S. Department of Education.

Ravitch, D. (1983). The troubled crusade. New York: Basic Books.

Rendón, L. (2002). Community college Puente: A validating model of education. Educational Policy, 16, 642-667. 
Riessmann, C.K. (1993). Narrative analysis. Newbury Park. CA: Sage.

Solórzano, D. G. (1998). Critical race theory, race and gender microaggressions, and the experience of Chicana and Chicano scholars. Qualitative Studies in Education, 11(1), 121-136.

Solórzano, D., \& Bernal, D. D. (2000). Examining transformational resistance through a critical race and Latcrit theory framework: Chicana and Chicano students in an urban context. Urban Education, 36(3), 308342.

Solórzano, D, \& Yosso, T. (2002). Critical race methodology: Counterstorytelling as an analytical framework for education research. Qualitative Inquiry, 8(1), 23-44.

Solórzano, D, Ceja, M., \& Yosso, T. (2000). Critical race theory, racial microaggressions, and campus racial climate: The experiences of African American college students. The Journal of Negro Education, 69, 1(2), 60-73.

Souleymane, Bachir, Diagne (2010). In Praise of the Post-racial: Negritude Beyond Negritude. Third Text, 24 (2), pp. 241-248.

Sparks, A. (2009). Minstrel politics or "he speaks too well:" rhetoric, race and resistance in the 2008 presidential campaign. Argumentation and Advocacy, 46, 21-38. 
Steele, C. M. (2009). A threat in the air: How stereotypes shape intellectual identity and performance. In E. Taylor, D. Gillborn, \& G. LadsonBillings (Eds.), Foundations of critical race theory in education (pp. 163-189). New York: Routledge.

Sue, D. W., Lin, A. I., Torino, G. C., Capodilupo, C. M., \& Rivera, D. P. (2009). Racial microaggressions and difficult dialogues on race in the classroom. Cultural Diversity and Ethnic Minority Psychology, 15(2), 183-190.

Sue, D. W., Nadal, K. L., Capodilupo, C. M., Lin, A. I., Torino, G. C., \& Rivera, D. P. (2008). Racial microaggressions against Black Americans: Implications for counseling. Journal of Counseling and Development, 86, 330-338.

Taylor, E. (2009). The foundations of critical race theory in education: An introduction. In E. Taylor, D. Gillborn, \& G. Ladson-Billings (Eds.), Foundations of critical race theory in education.] (pp. 1-13). New York: Routledge.

Taylor, E., Gillborn, D., \& Ladson-Billings, G. (2009). Foundations of critical race theory in education. New York: Routledge.

Valenzuela, A. (1999). Subtractive schooling: U.S.-Mexican youth and the politics of caring. New York: SUNY Press. 
Volkwein, J. F., King, M. C., \& Terenzini, P. T. (1986). Student-faculty relationships and intellectual growth among transfer students. Journal of Higher Education, 57(4), 413-430.

Yosso, T. (2000). A critical race and LatCrit approach to media literacy: Chicana/o reistance to visual microaggressions. Unpublished doctoral dissertation, Unviersity of California, Los Angeles. 


\section{Appendix A}

Research Findings pertaining to barriers and facilitators in African Americans in community colleges and higher education overall

\begin{tabular}{|c|c|c|c|c|c|c|c|c|}
\hline s & $\begin{array}{l}\text { Remedial } \\
\text { Programs }\end{array}$ & $\begin{array}{l}\text { African } \\
\text { American } \\
\text { Faculty \& } \\
\text { Career } \\
\text { Mentoringa }\end{array}$ & $\begin{array}{l}\text { African } \\
\text { Americans } \\
\text { Dis- } \\
\text { advantageda }\end{array}$ & $\begin{array}{l}\text { Inadequate } \\
\text { Transfer } \\
\text { Advicexi }\end{array}$ & $\begin{array}{l}\text { Orientation, } \\
\text { Advising } \\
\text { Understanding } \\
\text { Faculty, Bridge } \\
\text { Programsa }\end{array}$ & $\begin{array}{l}\text { Positive } \\
\text { Faculty } \\
\text { Connections } \\
\text { Parental } \\
\text { involvemento }\end{array}$ & $\begin{array}{l}\text { College } \\
\text { Staff-Self } \\
\text { Reflection } \\
\text { Bias } \\
\text { Awareness } \\
\text { to Reduce } \\
\text { Barriersa } \\
\end{array}$ & $\begin{array}{l}\text { Faculty- } \\
\text { Structured } \\
\text { Class } \\
\text { Discussions } \\
\text { that Combat- } \\
\text { Racisms }\end{array}$ \\
\hline Hughes $(2009) \mathrm{x}$ & $\mathrm{Na}$ & $a$ & a & $\mathrm{a}$ & 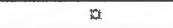 & $a$ & $a$ & $\mathrm{at}$ \\
\hline $\begin{array}{l}\text { Feist-Price } \\
(2001) \text { i }\end{array}$ & $a$ & $\mathrm{~Pa}$ & $\mathrm{Na}$ & $a$ & $a$ & $a$ & $a$ & $a$ \\
\hline $\begin{array}{l}\text { Dougherty- } \\
(1992) a\end{array}$ & st & a & $a$ & No & $a$ & $a$ & $a$ & $a$ \\
\hline $\begin{array}{l}\text { Dougherty } \\
\text { Reid (2007) a }\end{array}$ & $x$ & $a$ & $\mathrm{No}$ & $a$ & $a$ & $a$ & $a$ & $a$ \\
\hline $\begin{array}{l}\text { McGrath } \\
\text { Tobia (2008)a }\end{array}$ & $a$ & $\mathrm{~Pa}_{\mathrm{a}}$ & $a$ & 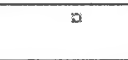 & $a$ & $a$ & $a$ & $a$ \\
\hline Glenn (2004)a & $a$ & $a$ & $\mathrm{ar}$ & $a$ & $\mathrm{Pri}_{\mathrm{r}}$ & $a$ & 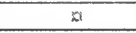 & $\pi$ \\
\hline Hare 2004$) \mathrm{o}$ & $a$ & 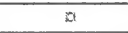 & $a$ & 5 & $a$ & $\mathrm{~Pa}$ & $a$ & $a$ \\
\hline $\begin{array}{l}\text { Wolkixein King } \\
\text { Tereazin } \\
(1986) \text { at }\end{array}$ & $a$ & $a$ & $a$ & $a$ & $a$ & $P a$ & $a$ & $\pi$ \\
\hline $\begin{array}{l}\text { Derby Watson } \\
(2006)\end{array}$ & a & $a$ & $a$ & $a$ & $a$ & $a$ & $P a$ & a \\
\hline $\begin{array}{l}\text { Greene Marti- } \\
\text { Medennex } \\
(2008) x\end{array}$ & $a$ & a & $a$ & $a$ & $\mathrm{Pat}$ & $a$ & $a$ & $n$ \\
\hline $\begin{array}{l}\text { Museus } \\
\text { Wichools y ambe } \\
\text { it }(2008) \text { in }\end{array}$ & $a$ & $x$ & ar & a & $a$ & $a$ & $a$ & $\mathrm{~Pa}$ \\
\hline
\end{tabular}

Note $P=$ positive correlation $X=$ no correlation, $-N=$ negative correlation, blank $=\cdot$ no dataf 


\section{Appendix B}

\section{Research Questions}

Research Question

How do African American students experience the transfer process in the East Bay Community College District?

What are the major barriers and facilitators to successful transfer?
Interview Question

Why did you choose to attend this community college(s)?

What services did you use at that community college?

Did you apply for scholarships?

What people or services were the most beneficial to you for transferring to SFSU?

Why do you think you were successful?

Did anyone give you personal support or strength at your community college that helped you to transfer to SFSU?

What are some examples of how they supported you?

What did you struggle with as you prepared to transfer? What were some of the major obstacles?

How do you think your experience was unique as an African American? Do you think it was different because you are Black?

Have you ever been treated differently in a college classroom because you're African American? Tell me 
experiences?

about your experiences.

How is your experience at SFSU? 


\section{Appendix C}

Demographic information of the colleges of participants in the 2007 academic yeart

\begin{tabular}{|c|c|c|c|c|c|c|c|c|c|c|}
\hline Collegea & Whitea & Blacka & \begin{tabular}{l|} 
Asian $\pi$ \\
Pacific \\
Islander
\end{tabular} & Filipinos & Latinon & $\begin{array}{l}\text { Native } \\
\text { Americans }\end{array}$ & Othera & $\begin{array}{l}\text { Non } \\
\text { residentat }\end{array}$ & $\begin{array}{l}\text { No } \\
\text { responsea }\end{array}$ & Totals \\
\hline$x$ & $a$ & 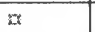 & $\alpha$ & $n$ & $a$ & $a$ & $a$ & $a$ & $x$ & $x$ \\
\hline $\begin{array}{l}\text { College } \\
\text { Onea: }\end{array}$ & 98102 & 11410 & $2725 \pi$ & $1165 a$ & $2841 a$ & $128 x$ & $689 a$ & $940 x$ & $1352 \pi$ & 207910 \\
\hline 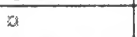 & $x$ & $a$ & $a$ & $n$ & $x$ & $n$ & $a$ & $a$ & $a$ & $a$ \\
\hline $\begin{array}{l}\text { College } \\
\text { Tivon }\end{array}$ & $3389 a$ & $1359 a$ & $509 a$ & $532 \pi$ & $2439 a$ & $80 a$ & $255 a$ & $17 a$ & $413 a$ & $8993 x$ \\
\hline$a$ & $a$ & $a$ & $a$ & $a$ & $a$ & $a$ & $a$ & $a$ & $a$ & 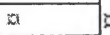 \\
\hline $\begin{array}{l}\text { College } \\
\text { Threen }\end{array}$ & $1464 a$ & $2065 a$ & $1144 a$ & $598=$ & 2227 & $44 a$ & $282 a$ & $128 x$ & $444 a$ & $8,396 a$ \\
\hline at & $x$ & $a$ & $a$ & $a$ & $\alpha$ & $a$ & $a$ & $a$ & $\mathrm{a}$ & 5 \\
\hline $\begin{array}{l}\text { San } \\
\text { Francisco } \\
\text { State } \\
\text { Universityd }\end{array}$ & $9423 a$ & $1710 a$ & $6085 a$ & $2446 x$ & $4393 a$ & $187 a$ & $1437 a$ & $1894 a$ & $2550 a$ & 30,125 \\
\hline Totals & $24,086 \times$ & $6.275 \pi$ & $10.463 x$ & $4741 \mathrm{a}$ & 119000 & $439 x$ & $2,663 \mathrm{a}$ & $2979 a$ & $3759 \pi$ & $68.305 x$ \\
\hline
\end{tabular}

ๆ

ศ 


\section{Appendix D}

\section{Pre- Interview Activity}

Instructions: Please write the following survival letter to an African American student working toward transfer at your old community college. Include the following things:
A. What are the top ten things they should know in order to transfer?
B. Who do they need to connect with for support? 


\section{Appendix E}

Interview Questions

1. Have you ever been treated differently in a Community College classroom because you're African American? Tell me about your experiences.

2. Why did you choose to attend college?

3. What people or services were the most beneficial to you for transferring to SFSU?

4. Why do you think you were successful?

5. How do you think your experience was unique as an African American? Do you think it was different because you are African American?

6. Did anyone give you personal support or strength at your community college that helped you to transfer to SFSU? 
7. What did you struggle with as you prepared to transfer? What were some of the major obstacles?

8. If you could talk to an administrator or faculty member at the $\mathrm{CC}$ you attended, how could they improve the transfer process for other African American students like you? 